Prepared in cooperation with the U.S. Environmental Protection Agency Region 4 Superfund Section

\title{
Geophysical Logging and Thermal Imaging Near the Hemphill Road TCE National Priorities List Superfund Site Near Gastonia, North Carolina
}

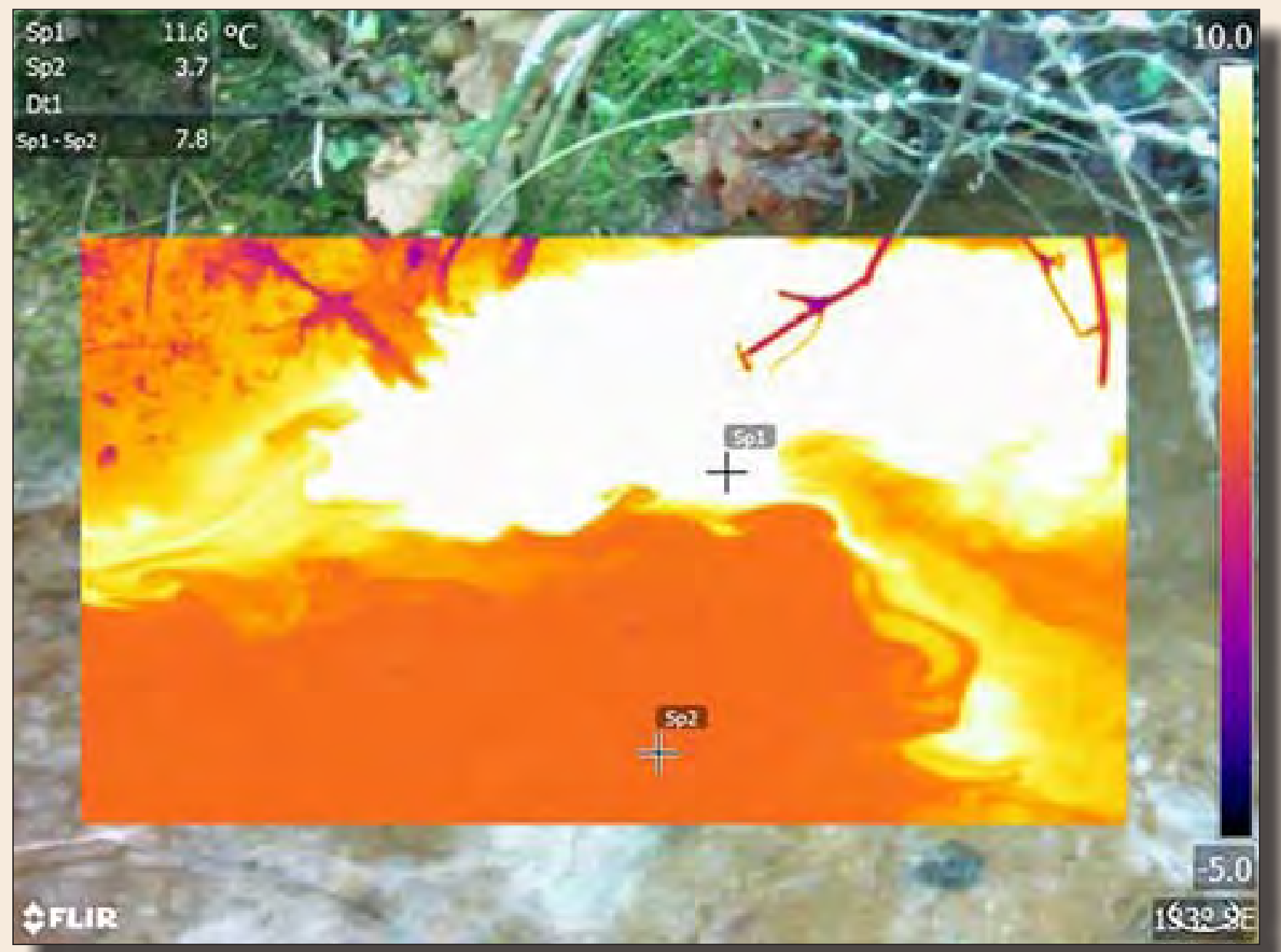

Open-File Report 2017-1017

Version 1.1, March 30, 2017 
Front cover. Thermal image showing groundwater seepage from stream bank at stream site FS-04 near Gastonia, North Carolina (February 2015). Photograph by Laura Gurley, USGS.

Back cover. Photograph showing deployment of borehole geophysical logging tool in well GS-293 near Gastonia, North Carolina (September 2014). Photograph by Dominick Antolino, USGS. 


\section{Geophysical Logging and Thermal Imaging Near the Hemphill Road TCE National Priorities List Superfund Site Near Gastonia, North Carolina}

By Dominick J. Antolino and Melinda J. Chapman

Prepared in cooperation with the U.S. Environmental Protection Agency

Region 4 Superfund Section

Open-File Report 2017-1017

Version 1.1, March 30, 2017 


\title{
U.S. Department of the Interior \\ RYAN K. ZINKE, Secretary
}

\section{U.S. Geological Survey William H. Werkheiser, Acting Director}

\author{
U.S. Geological Survey, Reston, Virginia: 2017 \\ First release: 2017 \\ Revised: March 30, 2017 (ver. 1.1)
}

\begin{abstract}
For more information on the USGS - the Federal source for science about the Earth, its natural and living resources, natural hazards, and the environment—visit http://www.usgs.gov or call 1-888-ASK-USGS.

For an overview of USGS information products, including maps, imagery, and publications, visit http://www.usgs.gov/pubprod/.
\end{abstract}

\author{
Any use of trade, firm, or product names is for descriptive purposes only and does not imply endorsement by the \\ U.S. Government. \\ Although this information product, for the most part, is in the public domain, it also may contain copyrighted materials \\ as noted in the text. Permission to reproduce copyrighted items must be secured from the copyright owner. \\ Suggested citation: \\ Antolino, D.J., and Chapman, M.J., 2017, Geophysical logging and thermal imaging near the Hemphill Road TCE \\ National Priorities List Superfund site near Gastonia, North Carolina (ver 1.1, March 30, 2017): U.S. Geological Survey \\ Open-File Report 2017-1017, 47 p., https://doi.org/10.3133/ofr20171017. \\ ISSN 2331-1258 (online)
}




\section{Contents}

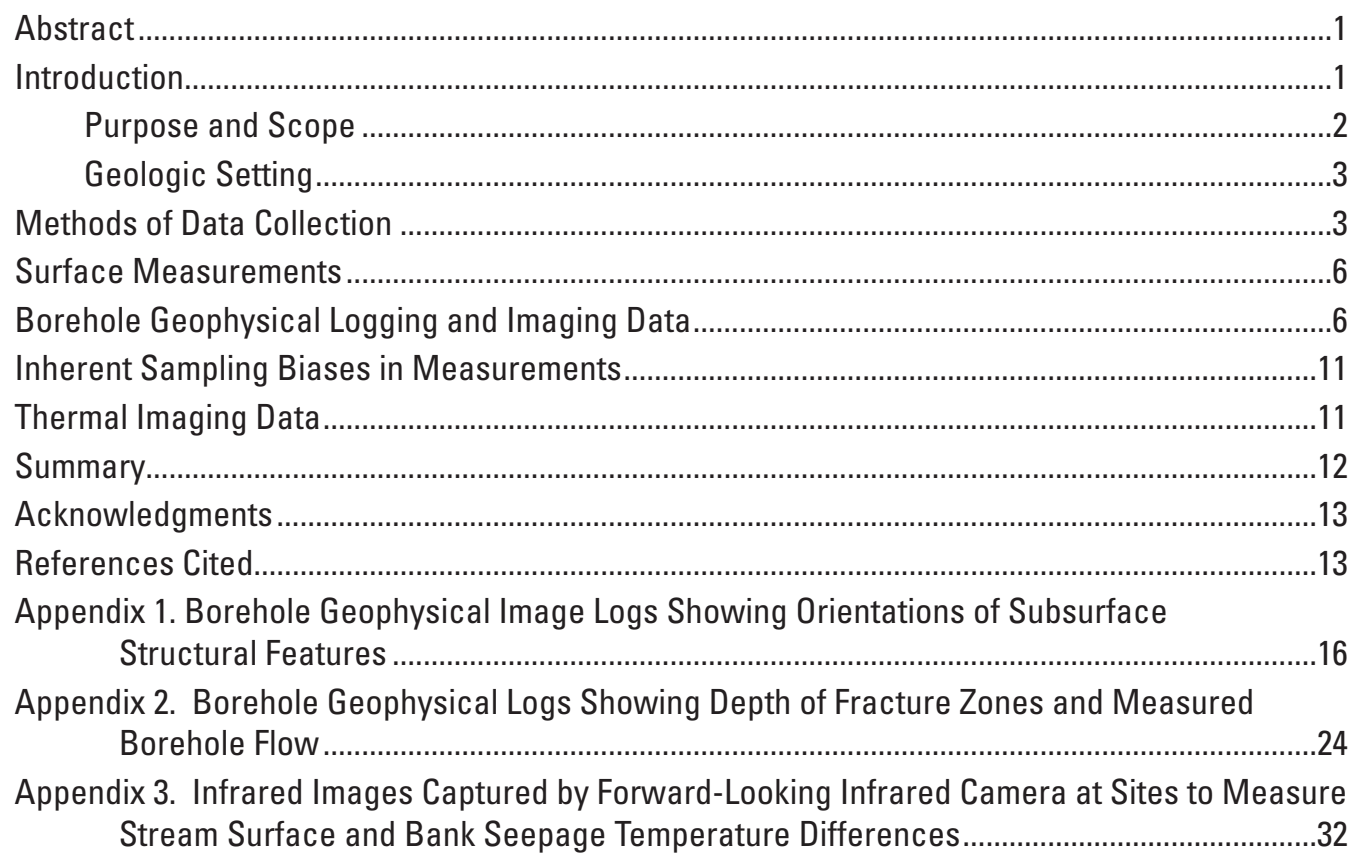

\section{Figures}

\section{1-3. Map showing}

1. Physiographic provinces in North Carolina, and the Hemphill Road TCE National Priorities List Superfund site and associated local geologic units, Gaston County, North Carolina

2. Topography near the Hemphill Road TCE National Priorities List Superfund site and new wells logged as part of the study, Gastonia, Gaston County, North Carolina.

3. Surface outcrop locations and distribution of structures measured near the Hemphill Road TCE National Priorities List Superfund site, Gastonia, Gaston County, North Carolina....

4. Strike orientation for all structures measured in the seven wells logged near the Hemphill Road TCE National Priorities List Superfund site, Gastonia, Gaston County, North Carolina. Length of petal corresponds to percent of the total number of measurements.

5. Strike orientation of subsurface foliation measurements from the seven wells logged near the Hemphill Road TCE National Priorities List Superfund site, Gastonia, Gaston County, North Carolina

6. Dominant orientations of open fractures measured in the seven wells derived from optical and acoustic televiewer image logs, near the Hemphill Road TCE National Priorities List Superfund site, Gastonia, Gaston County, North Carolina . 
7. Map showing well locations and distribution of subsurface structures measured in seven open borehole wells from optical and acoustic televiewer image logs near the Hemphill Road TCE National Priorities List Superfund site, Gastonia, Gaston County, North Carolina ...

8. Borehole geophysical logs from well GS-293 showing fracture zones and downward vertical flow at depth, near the Hemphill Road TCE National Priorities

List Superfund site, Gastonia, Gaston County, North Carolina

9. Borehole geophysical logs from well GS-294 showing fracture zones and upward vertical flow at depth, near the Hemphill Road TCE National Priorities List

Superfund site, Gastonia, Gaston County, North Carolina

10. Examples of infrared images captured by the Forward-Looking Infrared camera at FS-04 to determine stream surface and bank seepage temperatures in August 2014 and February 2015 near the Hemphill Road TCE National Priorities List Superfund site, Gastonia, Gaston County, North Carolina.

11. Map showing stream sites with stream surface and bank seepage temperature differences derived from Forward-Looking Infrared camera measurements in August and September 2014 and February 2015 near the Hemphill Road TCE National Priorities List Superfund site, Gastonia, Gaston County, North Carolina

\section{Tables}

1. Characteristics of the seven wells logged near the Hemphill Road TCE National

Priorities List Superfund site, Gastonia, Gaston County, North Carolina

2. U.S. Geological Survey Flow-Log Analysis of Single Holes program modeling results for heat-pulse flowmeter logs collected from the seven wells near the Hemphill Road TCE National Priorities List Superfund site, Gastonia, Gaston County, North Carolina.....

\section{Conversion Factors}

U.S. customary units to International System of Units

\begin{tabular}{|c|c|c|}
\hline Multiply & By & To obtain \\
\hline \multicolumn{3}{|c|}{ Length } \\
\hline inch (in.) & 2.54 & centimeter $(\mathrm{cm})$ \\
\hline inch (in.) & 25.4 & millimeter $(\mathrm{mm})$ \\
\hline foot $(\mathrm{ft})$ & 0.3048 & meter $(\mathrm{m})$ \\
\hline mile (mi) & 1.609 & kilometer $(\mathrm{km})$ \\
\hline \multicolumn{3}{|c|}{ Flow rate } \\
\hline gallon per minute (gal/min) & 0.06309 & liter per second $(\mathrm{L} / \mathrm{s})$ \\
\hline \multicolumn{3}{|c|}{ Transmissivity } \\
\hline foot squared per day $\left(\mathrm{ft}^{2} / \mathrm{d}\right)$ & 0.09290 & meter squared per day $\left(\mathrm{m}^{2} / \mathrm{d}\right)$ \\
\hline
\end{tabular}

Temperature in degrees Fahrenheit $\left({ }^{\circ} \mathrm{F}\right)$ may be converted to degrees Celsius $\left({ }^{\circ} \mathrm{C}\right)$ as follows:

$$
{ }^{\circ} \mathrm{C}=\left({ }^{\circ} \mathrm{F}-32\right) / 1.8
$$




\section{Datum}

Vertical coordinate information is referenced to the North American Vertical Datum of 1988 (NAVD 88).

Horizontal coordinate information is referenced to the North American Datum of 1983 (NAD 83).

\section{Supplemental Information}

Transmissivity: The standard unit for transmissivity is cubic foot per day per square foot times foot of aquifer thickness $\left(\left[\mathrm{ft}^{3} / \mathrm{d}\right] / \mathrm{ft}^{2}\right) \mathrm{ft}$. In this report, the mathematically reduced form, foot squared per day $\left(\mathrm{ft}^{2} / \mathrm{d}\right)$, is used for convenience.

Concentrations of trichloroethylene are given in micrograms per liter $(\mu \mathrm{g} / \mathrm{L})$.

Specific conductance is given in microsiemens per centimeter at 25 degrees Celsius $(\mu \mathrm{S} / \mathrm{cm}$ at $\left.25^{\circ} \mathrm{C}\right)$.

Natural gamma $(\gamma)$ radiation is given in American Petroleum Institute Units (APIU).

Resistivity is given in ohm meters $(\Omega-\mathrm{m})$, and resistance is given in ohms $(\Omega)$.

\section{Abbreviations}

FLASH Flow-Log Analysis of Single Holes

FLIR Forward-Looking Infrared

NPL National Priorities List

ppm parts per million

TCE trichloroethylene

USGS U.S. Geological Survey 



\title{
Geophysical Logging and Thermal Imaging Near the Hemphill Road TCE National Priorities List Superfund Site Near Gastonia, North Carolina
}

\author{
By Dominick J. Antolino and Melinda J. Chapman
}

\begin{abstract}
Borehole geophysical logs and thermal imaging data were collected by the U.S. Geological Survey near the Hemphill Road TCE (trichloroethylene) National Priorities List Superfund site near Gastonia, North Carolina, during August 2014 through February 2015. In an effort to assist the U.S. Environmental Protection Agency in the development of a conceptual groundwater model for the assessment of current contaminant distribution and future migration of contaminants, surface geological mapping and borehole geophysical log and thermal imaging data collection, which included the delineation of more than 600 subsurface features (primarily fracture orientations), was completed in five open borehole wells and two private supply bedrock wells. In addition, areas of possible groundwater discharge within a nearby creek downgradient of the study site were determined based on temperature differences between the stream and bank seepage using thermal imagery.
\end{abstract}

\section{Introduction}

The Hemphill Road TCE (trichloroethylene) National Priorities List (NPL) Superfund site study area is near the intersection of Hemphill Road and Safeway Drive, about 4 miles south of Gastonia, Gaston County, North Carolina (figs. 1 and 2). Regionally, the study area is in the Piedmont physiographic province in North Carolina, within the foliated to massive granitic rock known as the High Shoals Granite in the Kings Mountain sequence of the Carolina terrane, which includes the Battleground and Blacksburg Formations (Horton, 2008; Horton and others, 1981; fig. 1).

The groundwater system in the Piedmont physiographic province is complex, consisting of a two-part system of shallow, weathered regolith and deeper fractured bedrock. In some areas, a transition zone may develop between the shallow regolith and deeper bedrock, and permeability is enhanced near the top of bedrock with increased fracture density (Chapman and others, 2005; Huffman and others, 2006; McSwain and others, 2009, 2013; and Pippin and others, 2008). The community and private groundwater-supply wells in the area are completed within the bedrock section of the groundwater system, where water moves through secondary fractures and other complex discontinuities, such as differential weathering along lithologic contacts; thus, the mapping of fractures and other geologic features is critical to the understanding of groundwater transport to wells and the delineation of pathways of contaminant transport.

Operations at a former chemical drum recycling facility in the 1950s have resulted in the presence of a volatile organic compound plume in groundwater in the area that has affected private and community drinking-water wells near the study area. The Hemphill Road TCE site was placed on the Superfund program's NPL in 2013. In total, 7 communitysupply wells and more than 50 private wells are present within a 1-mile radius of the site (U.S. Environmental Protection Agency, 2013). The active community-supply wells within a 0.5 -mile radius serve 935 people, and 47 private wells serve 154 people (J.M. Waller Associates, 2014). In 2012, detected concentrations of TCE in groundwater from communitysupply and private wells ranged from 0.10 to 210 micrograms per liter ( $\mu \mathrm{g} / \mathrm{L})$ (U.S. Environmental Protection Agency, 2013). The U.S. Environmental Protection Agency sets the maximum contaminant level for TCE in water at $5 \mu \mathrm{g} / \mathrm{L}$ with a goal of $0 \mu \mathrm{g} / \mathrm{L}$ (U.S. Environmental Protection Agency, 2016). One community-supply well and six private wells contained TCE.

In March 2014, the U.S. Geological Survey (USGS) received a request to assist the U.S. Environmental Protection Agency Region 4 Superfund Section in the development of a conceptual groundwater model in the area of the Hemphill Road TCE NPL Superfund site near Gastonia, N.C. The USGS approach included the application of established and stateof-the-science borehole geophysical tools and methods used to delineate and characterize fracture zones in the regolithfractured bedrock groundwater system toward assistance with a conceptual model of flow in the bedrock part of the groundwater system. 


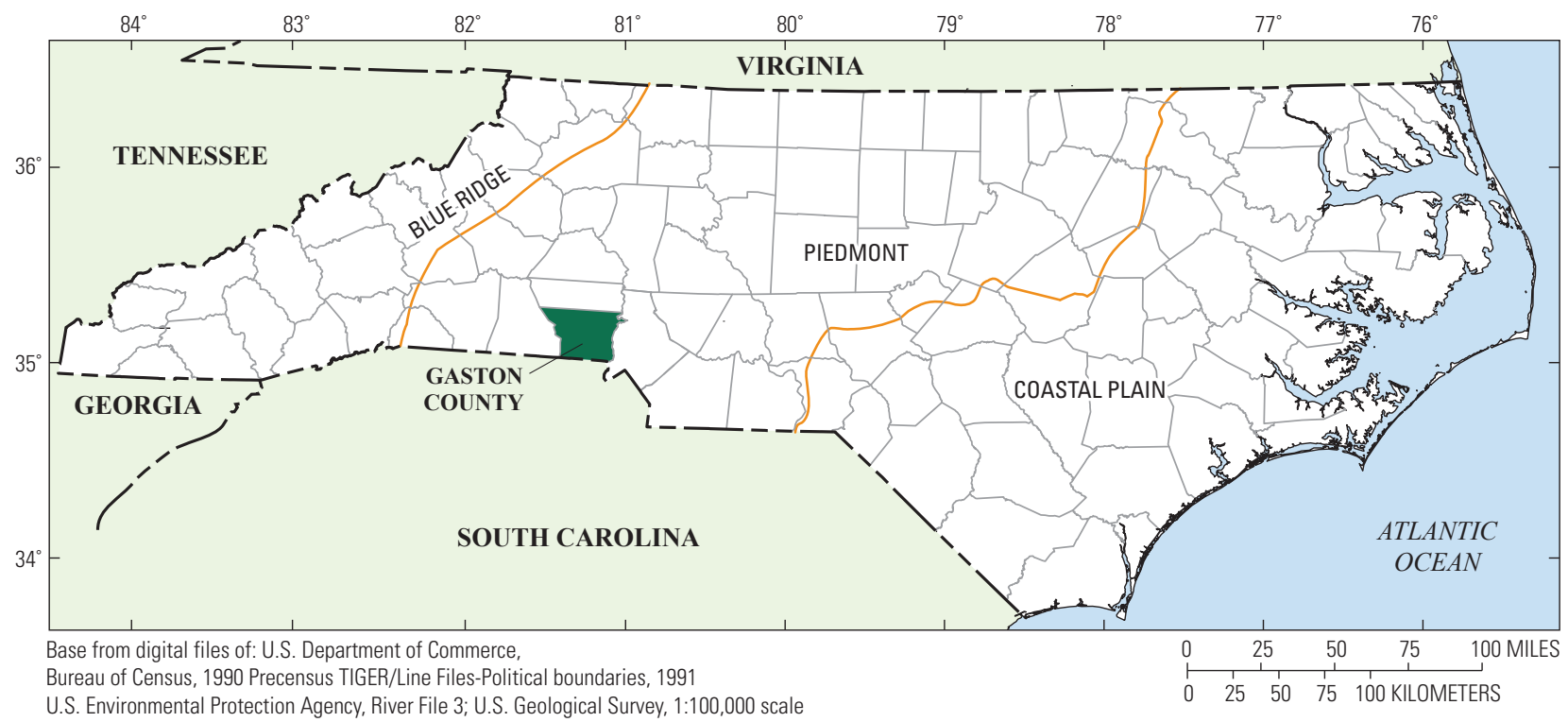

U.S. Environmental Protection Agency, River File 3; U.S. Geological Survey, 1:100,000 scale

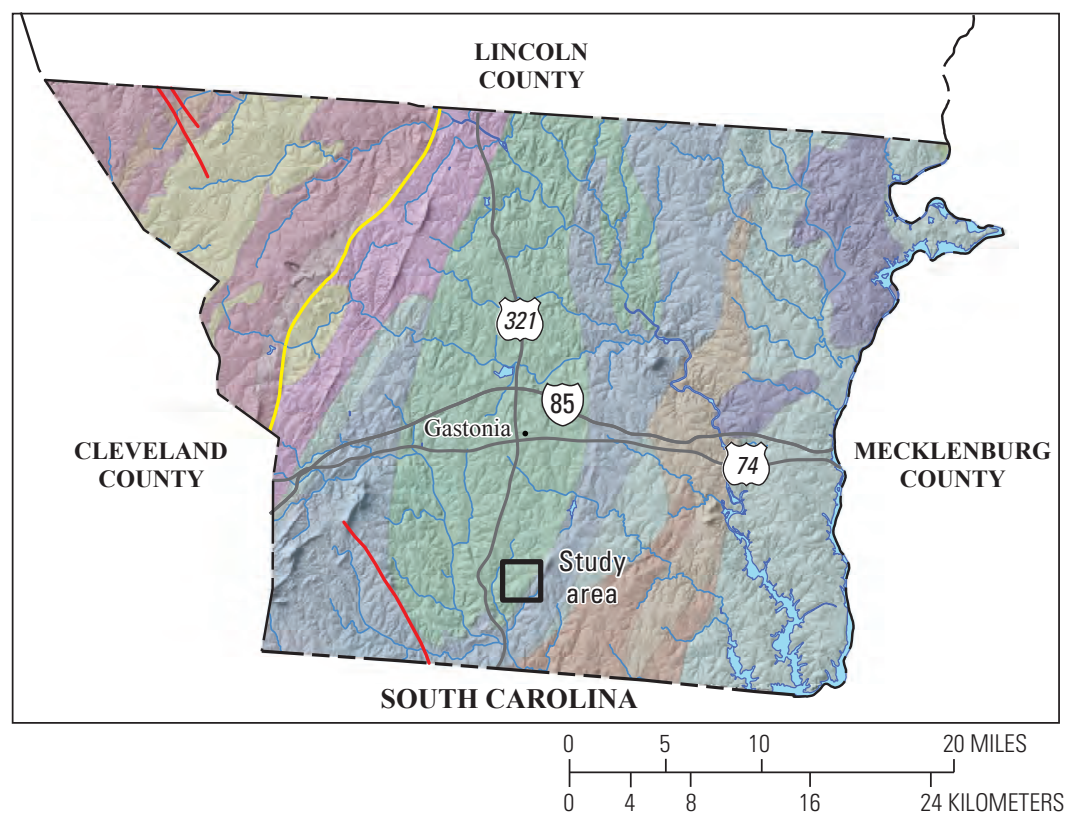

\section{EXPLANATION}

Geologic formation

Amphibolite and biotite gneiss Battleground Formation Blacksburg Formation Cherryville granite

Felsic metavolcanic rock High Shoals Granite (foliated to massive granitic rock)

Monzogranite and metagranodiorite Metamorphosed granitic rock Metamorphosed quartz diorite Mica schist

Physiographic province boundary Fault

Dike

Figure 1. Physiographic provinces in North Carolina, and the Hemphill Road TCE National Priorities List Superfund site and associated local geologic units, Gaston County, North Carolina.

\section{Purpose and Scope}

The purpose of this report is to present geophysical logging, geological mapping, and thermal imaging data collected near the Hemphill Road TCE NPL Superfund site near Gastonia, N.C. (fig. 1). Borehole geophysical logs and surface geologic mapping methods were used to characterize subsurface and surface features in the fractured bedrock and overlying regolith near the Hemphill Road TCE NPL Superfund Site. Geologic mapping was completed within a 0.5 -mile radius of the site and resulted in the collection of data at 17 stations. Thermal imaging was completed at 10 sites within a nearby stream downgradient from the site, highlighting areas of notable temperature differences between stream and streambank inflow that may signify groundwater discharge. 


\section{Geologic Setting}

On the local scale, the Hemphill Road TCE NPL Superfund site lies within the High Shoals Granite (fig. 1) with the contact with the Battleground Formation to the southeast. Rocks within the Kings Mountain sequence (formerly referred to as Kings Mountain Belt) are described by Goldsmith and others (1988) as distinctive metasedimentary and metavolcanic rocks having steep dips and lower metamorphic grades compared to nearby geologic terranes. From this regional geologic map, geologic units near the study area include the High Shoals Granite and the Battleground Formation. The Pennsylvanian age High Shoals Granite is described as a coarse grained, porphyritic, well-foliated gneissoid biotite granite or granitic gneiss that is part of a larger batholith within the Kings Mountain sequence county rocks. The Late Proterozoic age Battleground Formation is described as a quartz-sericite schist and phyllite. Structural data from Goldsmith and others (1988) recorded near the U.S. Environmental Protection Agency Hemphill Road TCE NPL site measured foliation from the High Shoals Granite striking $\mathrm{N} 50^{\circ} \mathrm{E}$ and dipping $85^{\circ} \mathrm{NW}$ with a joint set striking $\mathrm{N} 30^{\circ} \mathrm{E}$ and dipping $78^{\circ} \mathrm{NW}$. A nearby foliation measured in the Battleground Formation strikes $\mathrm{N} 50^{\circ} \mathrm{E}$ and dipping $76^{\circ} \mathrm{NW}$.

Groundwater systems within the Piedmont and Blue Ridge physiographic provinces in the southeastern United States are usually complex as a result of multiple periods of structural deformation, metamorphism, and igneous intrusion. Consisting of two components, the groundwater system in the Piedmont physiographic province includes a shallow, weathered regolith component that may include soil, saprolite, debris flow material, colluvium, and alluvium, in addition to a deeper fractured-bedrock component (Chapman and others, 2005). The shallow regolith acts as the primary storage reservoir and is the source of recharge to the deeper bedrock fractures (Heath, 1980, 1994). The bedrock has little primary porosity except where secondary openings are present in the form of fractures and other discontinuities. These secondary openings are the principal source of permeability within the bedrock.

\section{Methods of Data Collection}

In August and September 2014 and February 2015, borehole geophysical logs were collected from a total of five newly drilled, open-borehole wells and two private-supply bedrock wells within 0.25 mile of the Hemphill Road TCE NPL Superfund site (fig. 2; table 1). In addition to the borehole logging, a survey of surface outcrops in the area provided information on the structural features that could be later compared with the collected subsurface data (fig. 2).

Measurements were taken to determine the structure orientations of dominant joint sets and foliation in several bedrock outcrops near the study area. All planar features of structures were measured, where the strike is defined as the compass orientation of a horizontal line intersecting that plane and the dip angle is the steepest angle of descent from the horizontal plane (ranging from $0^{\circ}$ for a horizontal feature to $90^{\circ}$ for a vertical feature). Strike azimuth is represented by the convention of $0^{\circ}$ and $360^{\circ}$ corresponding to true north, $90^{\circ}$ corresponding to east, $180^{\circ}$ corresponding to south, and $270^{\circ}$ corresponding to west. Strike and dip measurements were recorded using the right-hand rule, where the dip direction for the planar feature is to the right of the strike azimuth.

Logs collected from each of the seven wells included caliper, electrical resistivity, natural gamma, fluid temperature and specific conductance, heat-pulse flowmeter (ambient and stressed), optical televiewer, and acoustic televiewer. After cleaning with deionized water, rinse samples were collected from borehole logging tools before, between selected wells, and after the completion of logging. These rinse samples were analyzed for volatile organic compounds to ensure that no contaminants were transferred from well to well during the geophysical logging process. Analytical data from the borehole-logging tool rinse samples are available through the National Water Information System at https://doi.org/10.5066/F7P55KJN.

Characterization of subsurface bedrock structures from geophysical logging included the following: primary lithology, fracture characteristics, foliation (if present), as well as secondary lithologies and lithologic contacts. Fracture zone characteristics delineated in the seven wells that were logged as part of this study include the following: depth, strike orientation and dip angle, flow measurement, and modeled hydraulic characteristics. Fracture zones were delineated at depth in each well using all the borehole logs, including visual delineation from optical televiewer images, caliper $\log$ diameter increases, resistivity decreases (below the water level), and inflections or slope changes in the fluid temperature and specific conductance logs.

Continuous, oriented digital color images of the bedrock borehole were recorded from the optical televiewer image logs. The acoustic televiewer image logs display acoustic amplitude and transit time based on an ultrasound pulse-echo system, where lithology and structure changes can be identified regardless of water clarity or visible feature contrast. Both sets of logs are oriented with the use of a magnetometer within the borehole tool and, after accounting for local magnetic declination and borehole deviation, feature orientations can be determined. Interpretations of feature data were based on the optical televiewer and acoustic televiewer image logs using WellCAD software (Advanced Logic Technology, 2010). The orientations were corrected for the measured borehole deviation and a local magnetic declination of $7^{\circ}$ west (National Oceanic and Atmospheric Administration, 2015). WellCad was also used to produce rose diagrams to display delineated fracture orientations.

Possible productive fracture zones were selected for heatpulse flowmeter logging (stationary measurements of vertical borehole flow above and below the fracture zone) based on interpretations of the caliper, electrical resistivity, and fluid logs 
(temperature and specific conductance), as well as the optical televiewer and acoustic televiewer image logs. Flowmeter measurements were completed under ambient (natural flow) and stressed (pumped flow) conditions, and the results were loaded into the USGS Flow-Log Analysis of Single Holes (FLASH) program (Day-Lewis and others, 2011a, b) in order to model aquifer properties (hydraulic head differences, transmissivity, and radius of influence). Vertical upflow in the borehole was indicated by positive heat-flow measurements, whereas downflow was indicated by negative heat-flow measurements.

Thermal images were collected at 10 sites along a small stream within the study area with Forward-looking Infrared (FLIR) Systems T620 and T640 cameras. Other recent studies have used similar ground-based thermal infrared imaging techniques to qualitatively locate groundwater discharge along discrete features, such as fractures and faults, as well as diffuse seepage along stream banks (Deitchman and Loheide, 2009; Pandey and others, 2013). The nearby stream was surveyed using a FLIR camera to denote areas of temperature difference along stream banks. Sites of interest were those where temperature differences were observed between the stream surface and points of streambank inflow, more specifically where cooler streambank water was seen entering the relatively warmer stream during the summer and warmer streambank water flowing into the relatively cooler stream during the winter. Groundwater, being less susceptible to atmospheric temperature fluctuations, has a relatively stable temperature signature with little seasonality throughout the year, whereas surface water in the stream is more readily exposed to the atmosphere and reflects seasonal changes in temperature throughout the year; therefore, with this expected contrast in temperature, sites where groundwater may possibly be discharging into the stream along the banks were able to be identified. FLIR Tools was then used to process the images and extract representative temperature information. The results were used to provide reconnaissance for sampling site selection, as well as accessory information alongside water quality sampling that was completed by the U.S. Environmental Protection Agency along the stream.

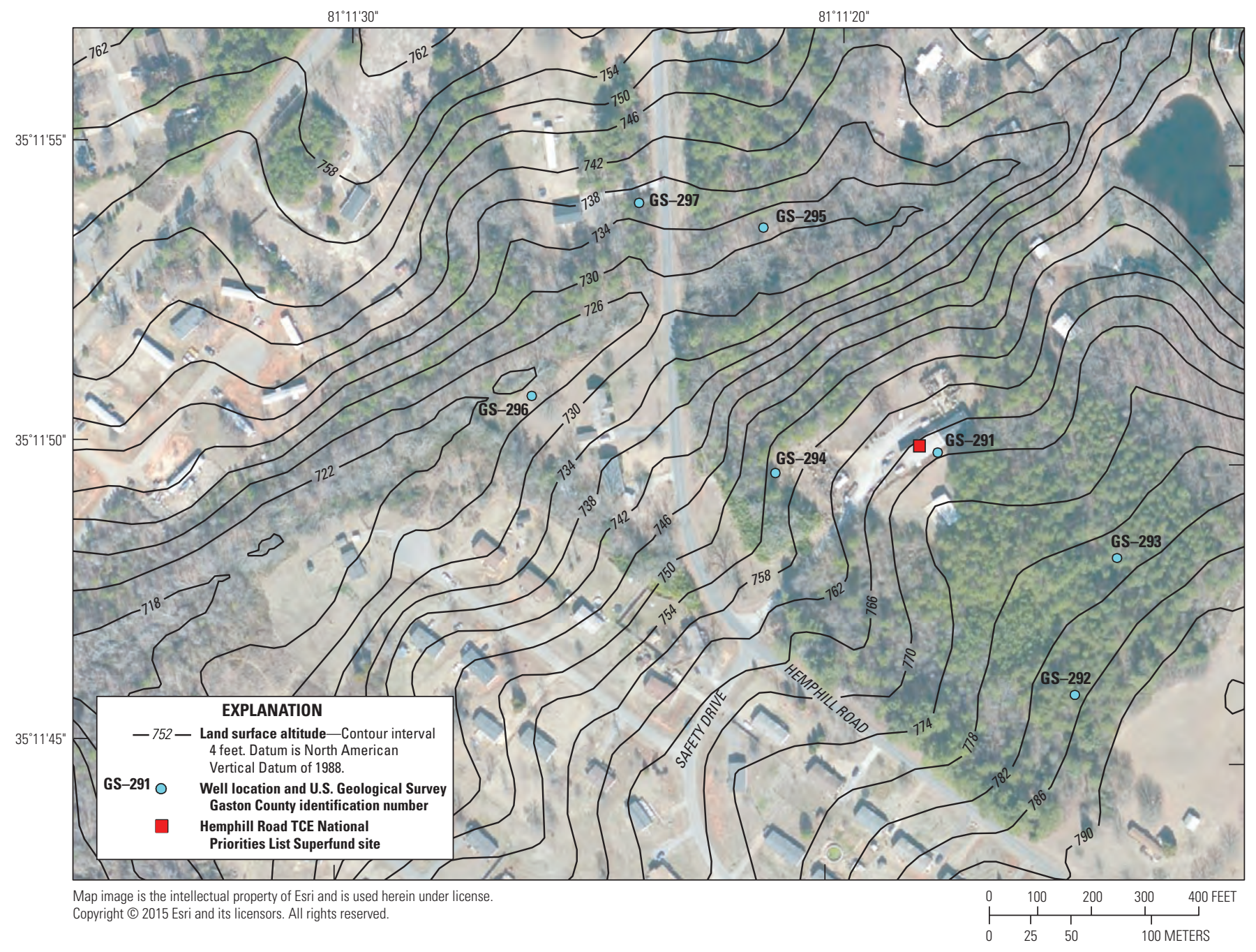

Figure 2. Topography near the Hemphill Road TCE National Priorities List Superfund site and new wells logged as part of the study, Gastonia, Gaston County, North Carolina. 
Table 1. Characteristics of the seven wells logged near the Hemphill Road TCE National Priorities List Superfund site.

[USGS, U.S. Geological Survey; ft, foot; bls, below land surface; NAVD 88, North American Vertical Datum of 1988.]

\begin{tabular}{|c|c|c|c|c|c|c|c|c|}
\hline $\begin{array}{c}\text { USGS site } \\
\text { identification } \\
\text { number }\end{array}$ & $\begin{array}{l}\text { USGS Gaston } \\
\text { County } \\
\text { identification } \\
\text { number (fig. 2) }\end{array}$ & $\begin{array}{l}\text { Dates logged and } \\
\text { associated water } \\
\text { level (ft bls) }\end{array}$ & $\begin{array}{l}\text { Decimal } \\
\text { latitude } \\
\text { (degree) }\end{array}$ & $\begin{array}{c}\text { Decimal } \\
\text { longitude } \\
\text { (degree) }\end{array}$ & $\begin{array}{c}\text { Land } \\
\text { surface } \\
\text { altitude } \\
\text { (ft above } \\
\text { NAVD 88) }\end{array}$ & $\begin{array}{l}\text { Measuring } \\
\text { point (ft above } \\
\text { land surface) }\end{array}$ & $\begin{array}{l}\text { USGS } \\
\text { logging } \\
\text { total depth } \\
\text { (ft bls) }\end{array}$ & $\begin{array}{l}\text { Casing } \\
\text { depth } \\
\text { logged } \\
\text { (ft bls) }\end{array}$ \\
\hline 351150081111801 & GS-291 & $\begin{array}{l}\text { a } 8 / 26 / 2014 ; 36.44 \\
\quad b 8 / 27 / 2014 ; 36.45\end{array}$ & 35.197 & -81.188 & 770 & 0.75 & 160 & 66 \\
\hline 351146081111501 & GS-292 & $\begin{array}{l}\text { a } 8 / 28 / 2014 ; 42.32 \\
\quad \text { b8/29/2014; } 41.54\end{array}$ & 35.196 & -81.188 & 786 & 1.50 & 200 & 100 \\
\hline 351148081111401 & GS-293 & $\begin{array}{l}\text { a9/3/2014; } 36.17 \\
\text { b9/4/2014; } 33.77\end{array}$ & 35.197 & -81.187 & 780 & 1.25 & 200 & 85 \\
\hline 351150081112101 & GS-294 & $\begin{array}{l}\text { a2/17/2015; } 23.30 \\
\text { b2/21/2015; } 23.30\end{array}$ & 35.197 & -81.189 & 755 & 2.00 & 280 & 53 \\
\hline 351153081112201 & GS-295 & $\begin{array}{l}\text { a2/10/2015; } 4.25 \mathrm{c} \\
\text { b2/22/2015; } 28.61 \mathrm{c}\end{array}$ & 35.198 & -81.189 & 730 & 2.00 & 300 & 61 \\
\hline 351151081112601 & GS-296 & $\begin{array}{l}\text { a2/17/2015; } 9.79 \\
\text { b2/18/2015; } 3.53\end{array}$ & 35.197 & -81.191 & 725 & 2.20 & 200 & 35 \\
\hline 351154081112401 & GS-297 & $\begin{array}{l}\text { a2/12/2015; } 15.38 \\
\text { b2/20/2015; } 15.34\end{array}$ & 35.198 & -81.190 & 740 & 1.58 & 201 & 86 \\
\hline
\end{tabular}

${ }^{a}$ Tier 1 caliper, electrical/fluid combo, optical and acoustic televiewer logging.

${ }^{b}$ Tier 2 heatpulse flowmeter logging.

${ }^{\mathrm{c}}$ Dry well conditions; clean water placed in well for logging purposes. 


\section{Surface Measurements}

Of the 17 outcrop measurements taken in the study area, the dominant strike orientations for most joint sets were $0^{\circ}-60^{\circ}$ trending north and northeast, with a secondary set having orientations $270^{\circ}-290^{\circ}$ trending west and northwest (fig. 3). Aside from two low angle measurements, dip angles ranging from $55^{\circ}$ to $90^{\circ}$ indicating near vertical joints were most frequently present within the surface outcrops. Foliation was measured within an outcrop containing large amounts of biotite, having a strike orientation of $246^{\circ}$ and a southeast dip near $60^{\circ}$.

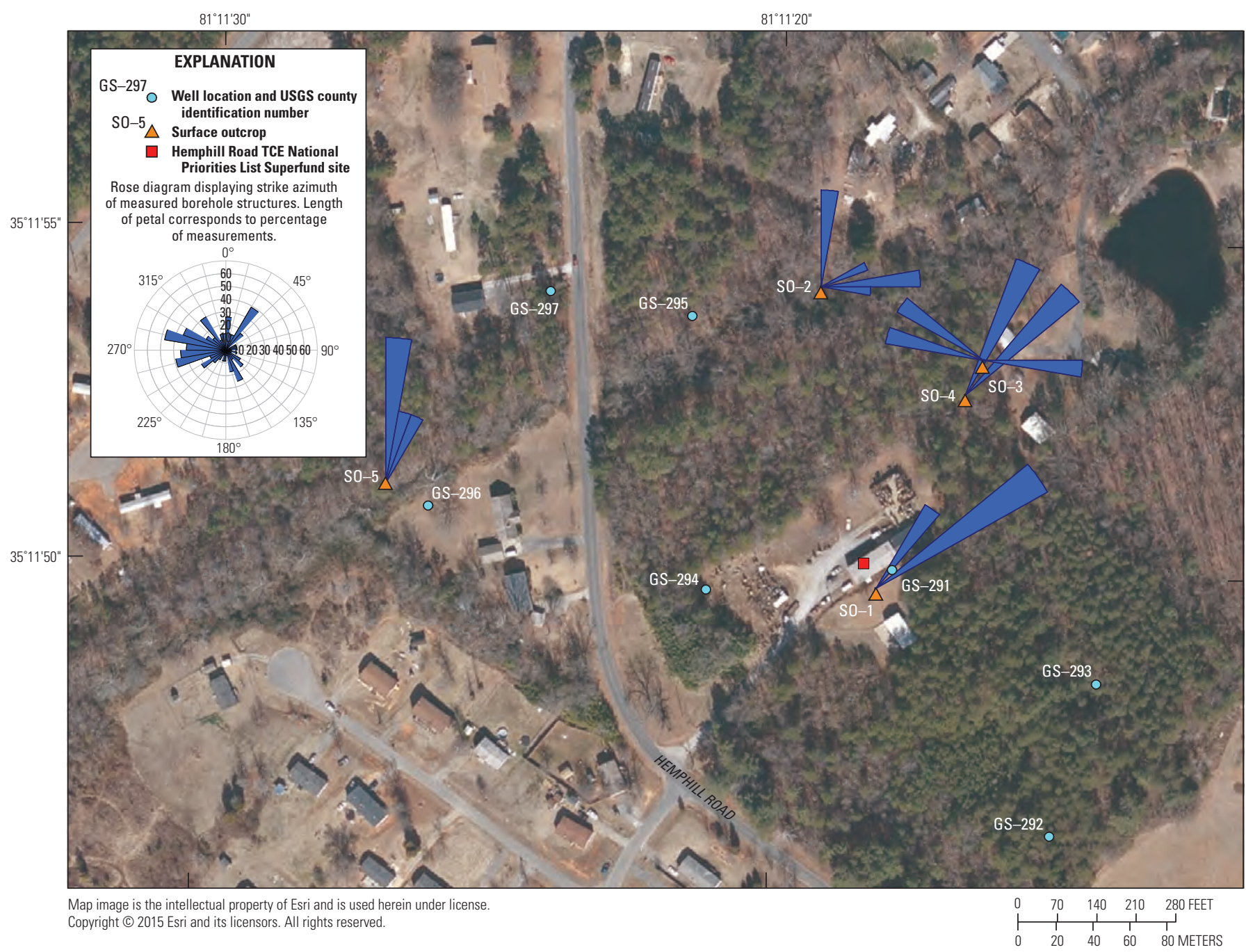

Figure 3. Surface outcrop locations and distribution of structures measured near the Hemphill Road TCE National Priorities List Superfund site, Gastonia, Gaston County, North Carolina.

\section{Borehole Geophysical Logging and Imaging Data}

The seven wells that were used for borehole geophysical logging were within a 0.25 -mile radius of the Hemphill Road TCE NPL Superfund site (fig. 2; table 1) Well depths ranged from 160 to 300 feet (ft) below land surface. Based on the compilation of casing depths, the regolith thickness inferred ranges from about 35 to $100 \mathrm{ft}$ below land surface, or 654 to $704 \mathrm{ft}$ above the North American Vertical Datum of 1988 (NAVD 88). Groundwater levels measured in all the wells during August and September 2014 ranged from 733.56 to $743.83 \mathrm{ft}$ above the NAVD 88, and during February 2015, ranged from 715.21 to $731.70 \mathrm{ft}$ above the NAVD 88.

The logs collected from the caliper, optical televiewer, and acoustic televiewer, along with the interpreted subsurface structure measurements within the granite bedrock and secondary textural features, are provided in appendix 1 
and in ScienceBase at https://doi.org/10.5066/F71R6NPM (Antolino and Chapman, 2017). Structures were characterized as either primary (open) fractures, secondary (partially open or weathered) fractures, sealed fractures (filled with secondary minerals), foliation, or lithologic contacts. More than 600 subsurface structural measurements (orientations) were interpreted from optical televiewer and acoustic televiewer images collected (see fig. 2 for well locations).

Strike orientations for all structures measured in the seven wells logged as part of this study are presented in figure 4 . The data indicate that the most common strike orientations were between $200^{\circ}-240^{\circ}$ and $350^{\circ}-10^{\circ}$. Subsurface structural orientations for individual wells are provided in ScienceBase at https://doi.org/10.5066/F71R6NPM (Antolino and Chapman, 2017). The dominant subsurface foliation orientation was $210^{\circ}-240^{\circ}$ (fig. 5), which parallels that of the surface foliation data collected from outcrop measurements. Open or primary subsurface fractures were between 65 and $210 \mathrm{ft}$ below land surface. The dominant strike orientations for the primary fractures were $0^{\circ}-20^{\circ}$ (depth ranged from 95 to $108 \mathrm{ft}$ below land surface) and $220^{\circ}-230^{\circ}$ (depth ranged from 119 to $208 \mathrm{ft}$ below land surface) (fig. 6); the median dip angle for the open fractures was $33^{\circ}$.

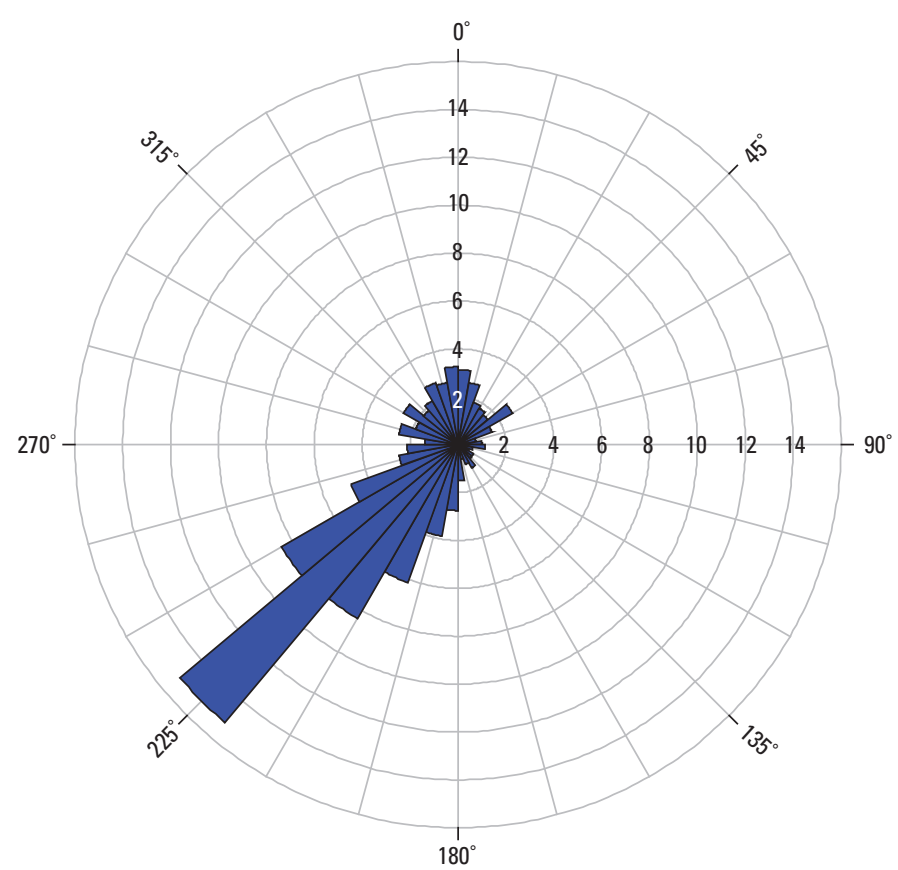

Figure 4. Strike orientation for all structures measured in the seven wells logged near the Hemphill Road TCE National Priorities List Superfund site, Gastonia, Gaston County, North Carolina. Length of petal corresponds to percent of the total number of measurements.

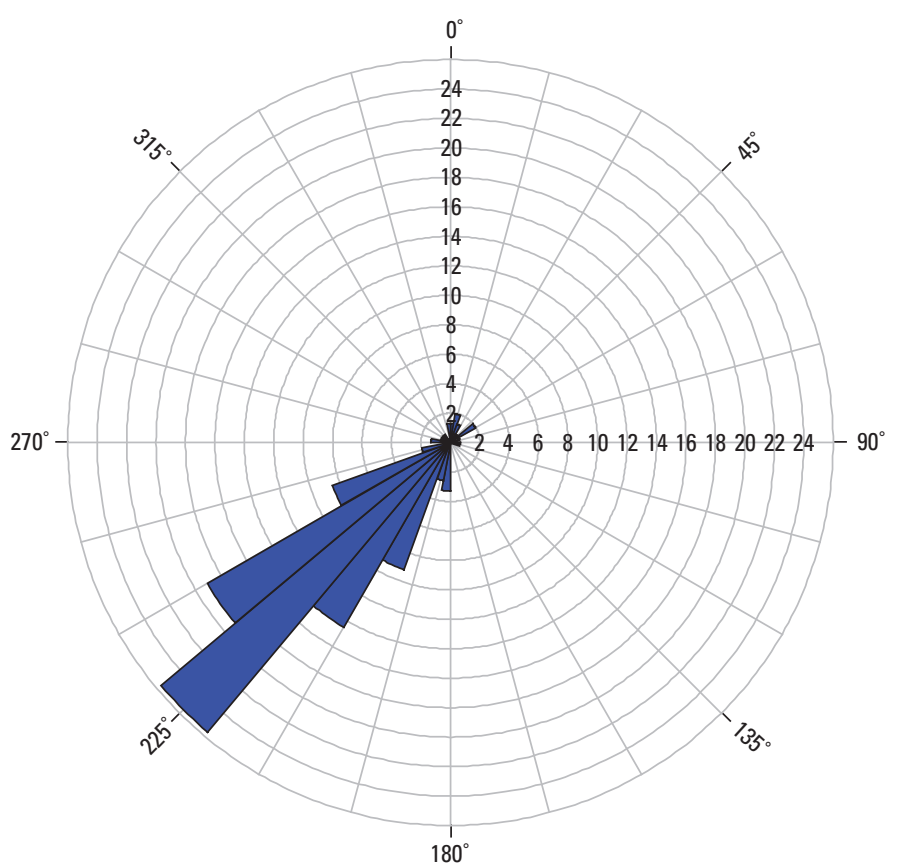

Figure 5. Strike orientation of subsurface foliation measurements from the seven wells logged near the Hemphill Road TCE National Priorities List Superfund site, Gastonia, Gaston County, North Carolina. Length of petal corresponds to percent of the total number of measurements.

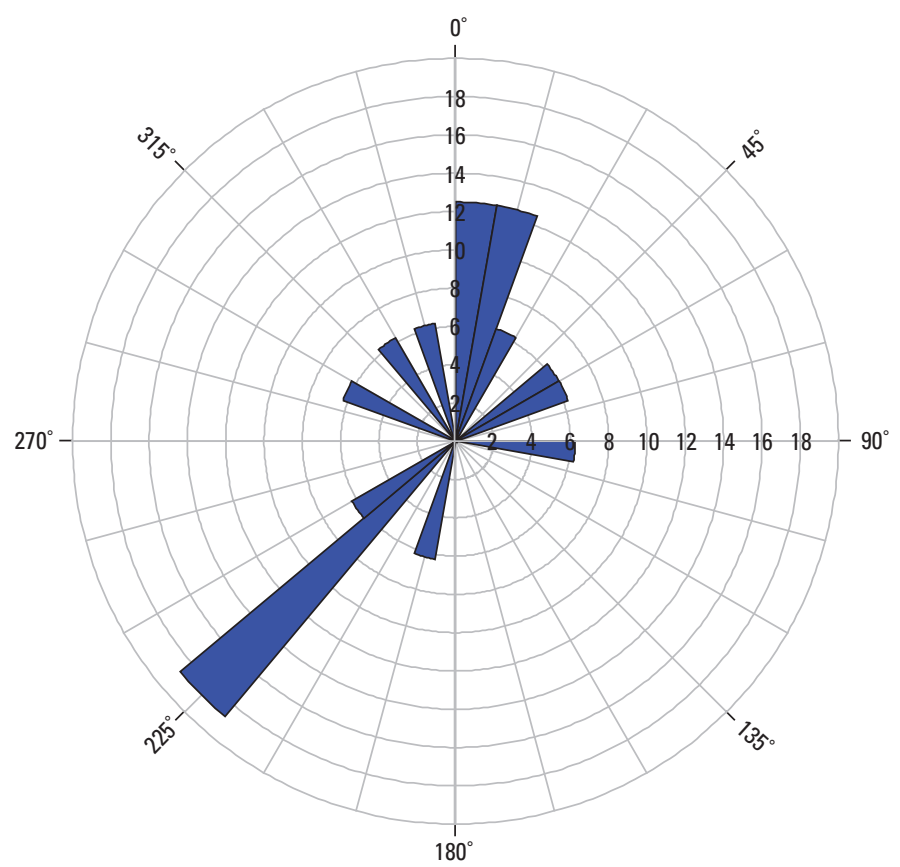

Figure 6. Dominant orientations of open fractures measured in the seven wells derived from optical and acoustic televiewer image logs, near the Hemphill Road TCE National Priorities List Superfund site, Gastonia, Gaston County, North Carolina. Length of petal corresponds to percent of the total number of measurements. 
The areal distribution of structures measured in the seven wells logged is shown in figure 7 . The most common dominant open fracture orientation within the wells measured was $220^{\circ}-240^{\circ}$, which was observed in all of the seven wells. Other dominant orientations observed in the wells were $0^{\circ}-30^{\circ}$ and $45^{\circ}-60^{\circ}$.

Sets of borehole geophysical logs in which fracture zones were delineated and flow was measured and modeled for each of the seven wells are provided in appendix 2 and in ScienceBase at https://doi.org/10.5066/F71R6NPM (Antolino and Chapman, 2017). Ambient vertical groundwater flow was measured in three of the seven wells: GS-293, GS-294, and GS-297. Most of the ambient flow measurements were near zero, indicating no flow. Values near the lower resolution of the heat-pulse flow meter of 0.01 and 0.02 gallons per minute were often considered noise and interpreted as no flow. In well GS-293 (fig. 8), flow comes into the borehole at the $88 \mathrm{ft}$ fracture zone, flows downward, and flows out of the borehole near the 170-ft fracture zone. In well GS-294 (fig. 9), inflow is modeled at the $141 \mathrm{ft}$ fracture zone, and flow continues upward until it flows outward near the $56 \mathrm{ft}$ fracture zone. FLASH modeling results often reduce the number of fractures that may be contributing flow, to the more dominant fracture zones. In several cases, multiple contributing fracture zones were initially modeled using FLASH, but the inclusion of certain less dominant zones resulted in vastly erroneous outputs (for example, head differences that exceeded plausible ranges). These less dominant fracture zones were thereby removed from the model.

Transmissivity estimates for the logged wells ranged from 0.6 to 214.7 feet squared per day $\left(\mathrm{ft}^{2} / \mathrm{d}\right)$ and estimates of the radius of influence ranged from 3.4 to $120 \mathrm{ft}$ (table 2). Initial estimates of transmissivity were made using empirical relations of specific capacity and transmissivity in fractured metamorphic and crystalline rocks (Srivastav and others, 2007). The range of the depths of fractures where flow was modeled were 58 to $277 \mathrm{ft}$ below land surface.

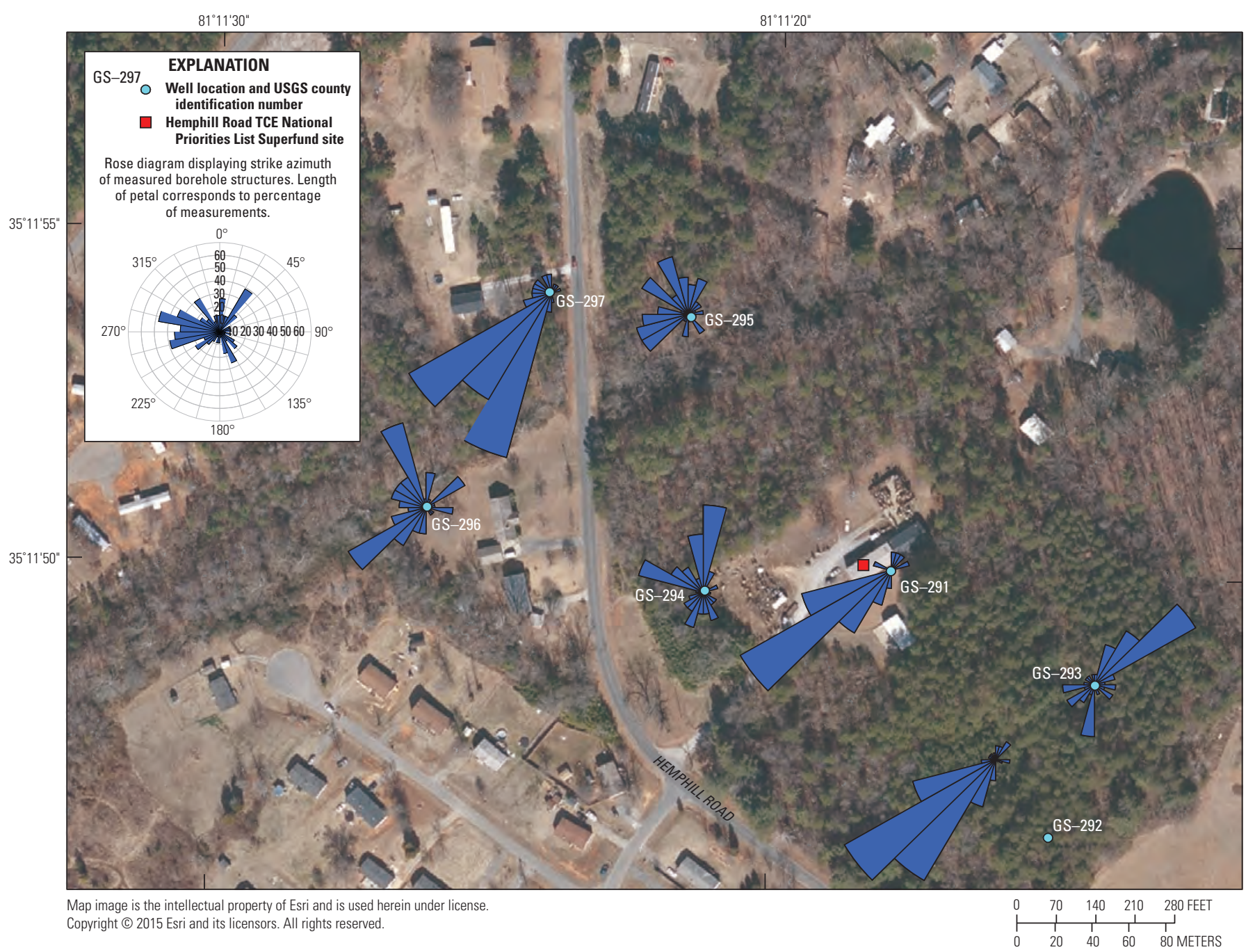

Figure 7. Well locations and distribution of subsurface structures measured in seven open borehole wells from optical and acoustic televiewer image logs near the Hemphill Road TCE National Priorities List Superfund site, Gastonia, Gaston County, North Carolina. 


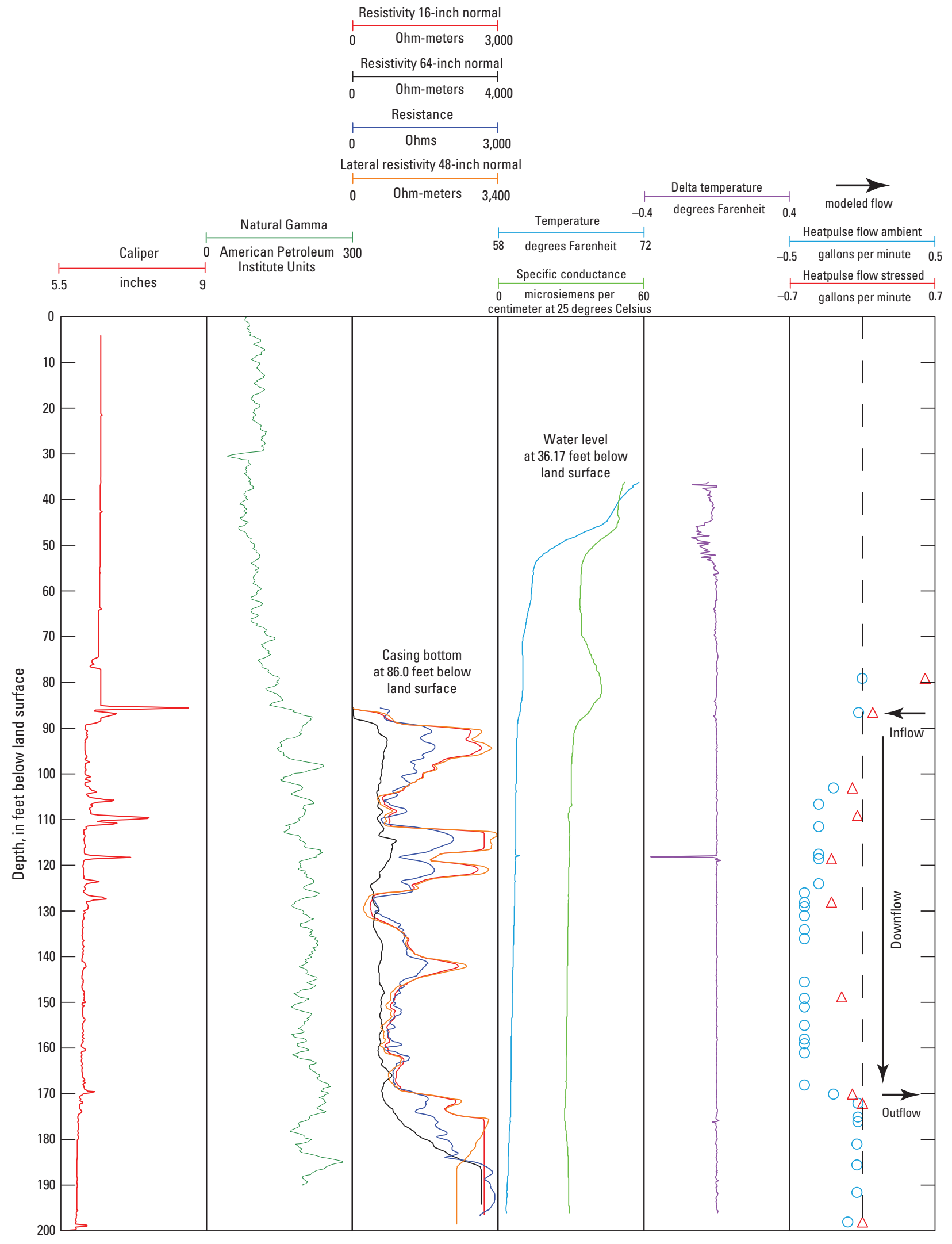

Figure 8. Borehole geophysical logs from well GS-293 showing fracture zones and downward vertical flow at depth, near the Hemphill Road TCE National Priorities List Superfund site, Gastonia, Gaston County, North Carolina. 


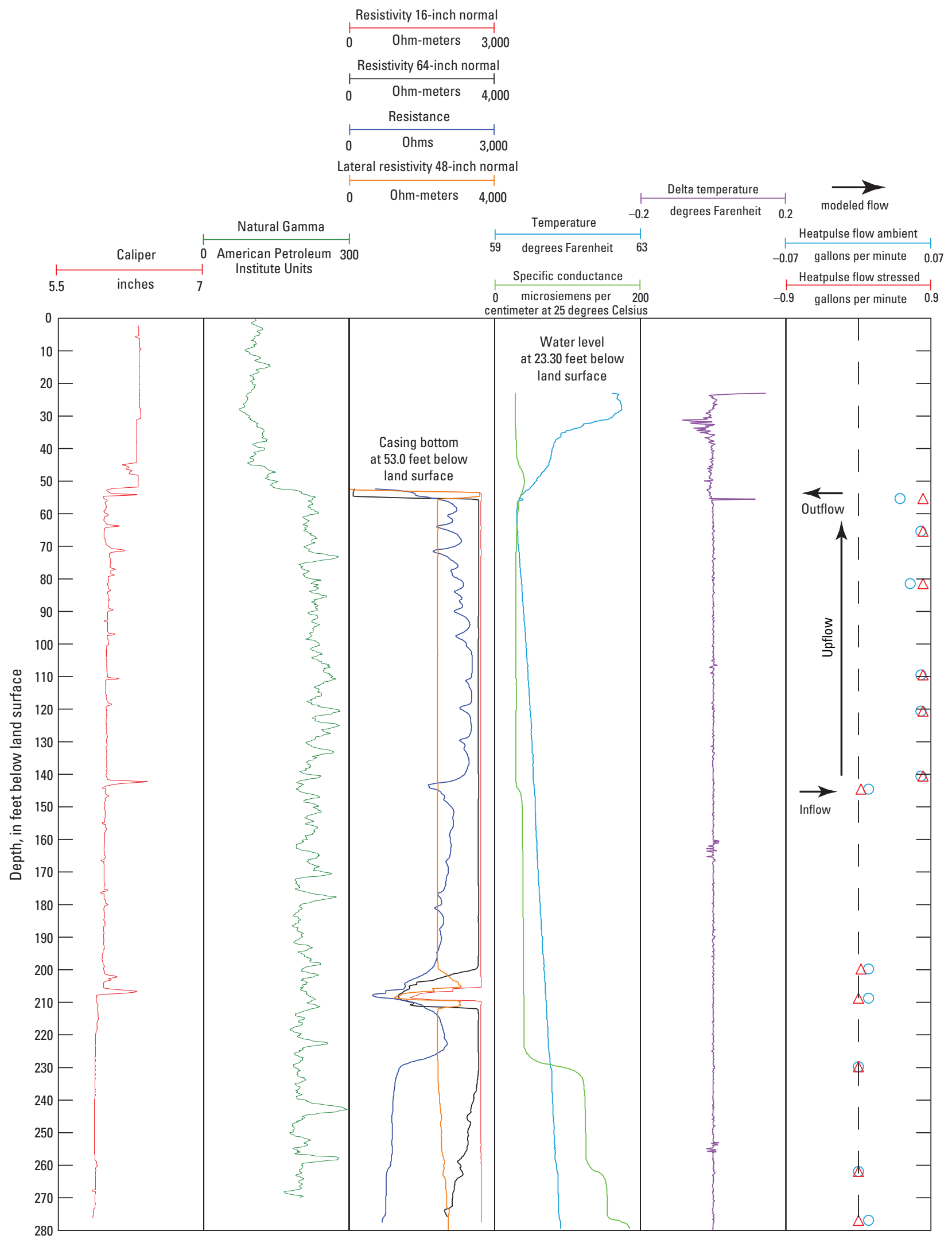

Figure 9. Borehole geophysical logs from well GS-294 showing fracture zones and upward vertical flow at depth, near the Hemphill Road TCE National Priorities List Superfund site, Gastonia, Gaston County, North Carolina. 
Table 2. FLASH program modeling results for heat-pulse flowmeter logs collected from the 10 wells near the Hemphill Road TCE National Priorities List Superfund site.

[USGS, U.S. Geological Survey; $\mathrm{ft}^{2} / \mathrm{d}$, foot squared per day; ft, foot; --, no data]

\begin{tabular}{lcc}
\hline $\begin{array}{c}\text { USGS Gaston County } \\
\text { identification number (fig. 2) }\end{array}$ & $\begin{array}{c}\text { Estimated } \\
\text { transmissivity } \\
\text { (ft'/d) }\end{array}$ & $\begin{array}{c}\text { Radius of } \\
\text { influence } \\
\text { (ft) }\end{array}$ \\
\hline GS-291 & 214.7 & 40.5 \\
GS-292 & 34.2 & 8.1 \\
GS-293 & 21.4 & 5.8 \\
GS-294 & 41.6 & 57.4 \\
GS-295 & 0.6 & -- \\
GS-296 & 20.5 & 3.4 \\
GS-297 & 26.5 & 120 \\
\hline
\end{tabular}

\section{Inherent Sampling Biases in Measurements}

There is some degree of difference present within the relative abundances of planar features counted between the surface and subsurface data within any given structural orientation. A likely explanation for this is that boreholes are less likely to intersect steeply dipping, near vertical planar features within the subsurface than more flat-lying, near horizontal features. In addition, surface outcrops provide more opportunity to measure steeply dipping features because only a short interval of the buried rock is exposed; that is, except in the case of high road cuts or cliff faces, both of which were not present within the study area. Furthering reasoning for the observed count disparity may also be due to differences in measurement representation, where individual features are measured within a borehole and yet a single outcrop measurement may represent an entire group of similar structural features.

\section{Thermal Imaging Data}

The FLIR camera captured thermal images from 10 sites along the small, unnamed stream that flows northeast to southwest in the northern section of the study area (figs. 10 and 11). Infrared images captured by the FLIR camera from all stream sites are provided for in appendix 3 and in ScienceBase at https://doi.org/10.5066/F71R6NPM (Antolino and Chapman, 2017). Site visits were done twice within the stream, once in August and September 2014 and then again for a subset of sites in February 2015. The site visits coincided with seasonal extremes; warmer stream temperatures during base-flow (cooler groundwater) conditions in the summer and cooler stream temperatures with warmer groundwater during the winter season. The subset of five sites visited in February 2015 were where previously observed stream surface and stream bank inflow temperature differences exceeded $3{ }^{\circ} \mathrm{C}$.

During the summer survey, the median surface temperatures recorded by the FLIR camera were $19.5^{\circ} \mathrm{C}$ for bank inflow and $22.5^{\circ} \mathrm{C}$ for the stream. During the winter survey, the FLIR recorded median surface temperatures of $8.7{ }^{\circ} \mathrm{C}$ for bank inflow and $3.6^{\circ} \mathrm{C}$ for the stream. The temperature differences between bank inflow and the stream ranged from 0.5 to $4.5^{\circ} \mathrm{C}$ for the summer survey and from 3.6 to $7.9^{\circ} \mathrm{C}$ for the winter survey. Results from the processed thermal images indicate at least five sites of potential groundwater input into the stream from the streambank (SW-03, SW-04, SW-08, SW-09, and SW-10).
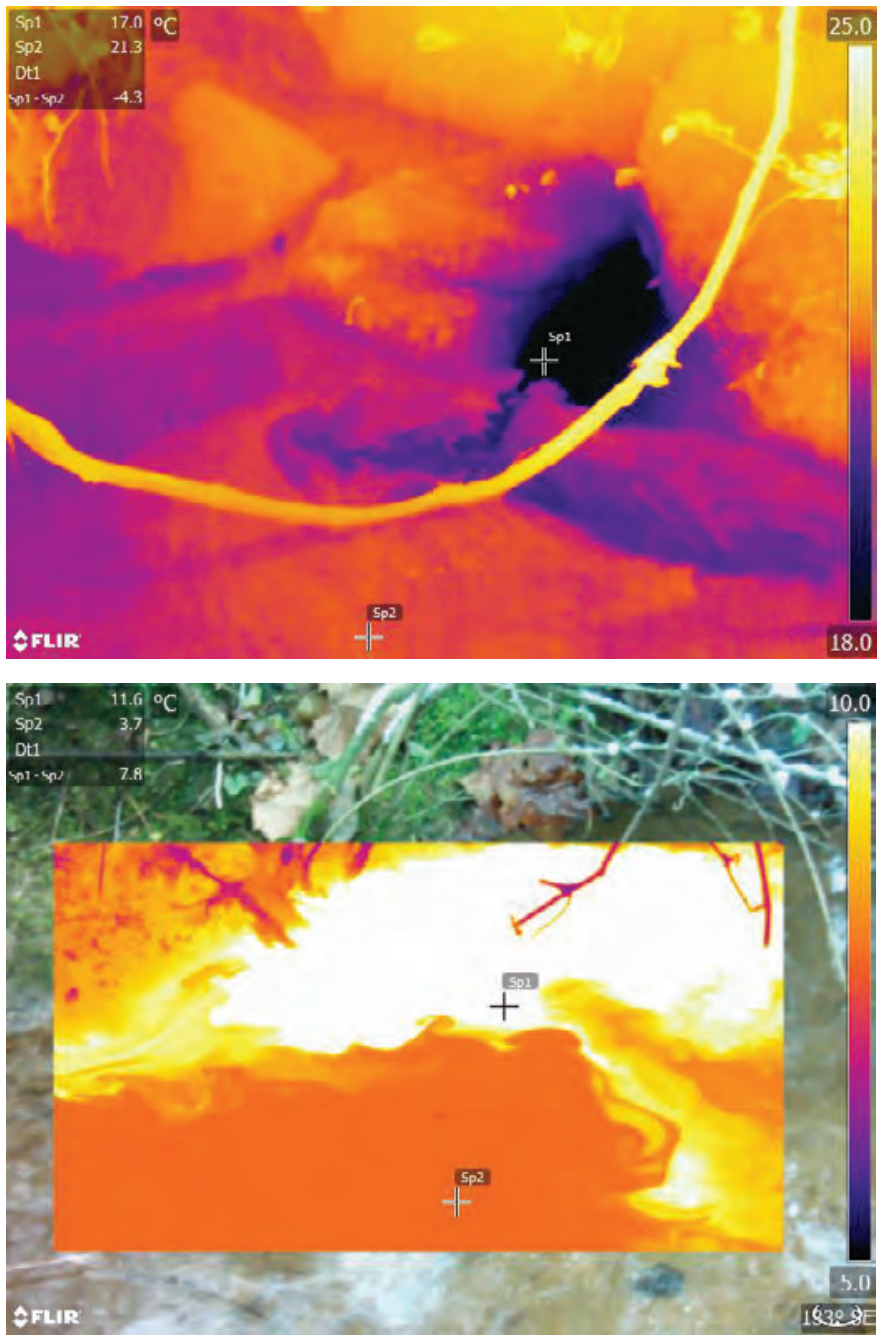

Figure 10. Examples of infrared images captured by the Forward-Looking Infrared camera at FS-04 to determine stream surface and bank seepage temperatures in August 2014 and February 2015 near the Hemphill Road TCE National Priorities List Superfund site, Gastonia, Gaston County, North Carolina. 


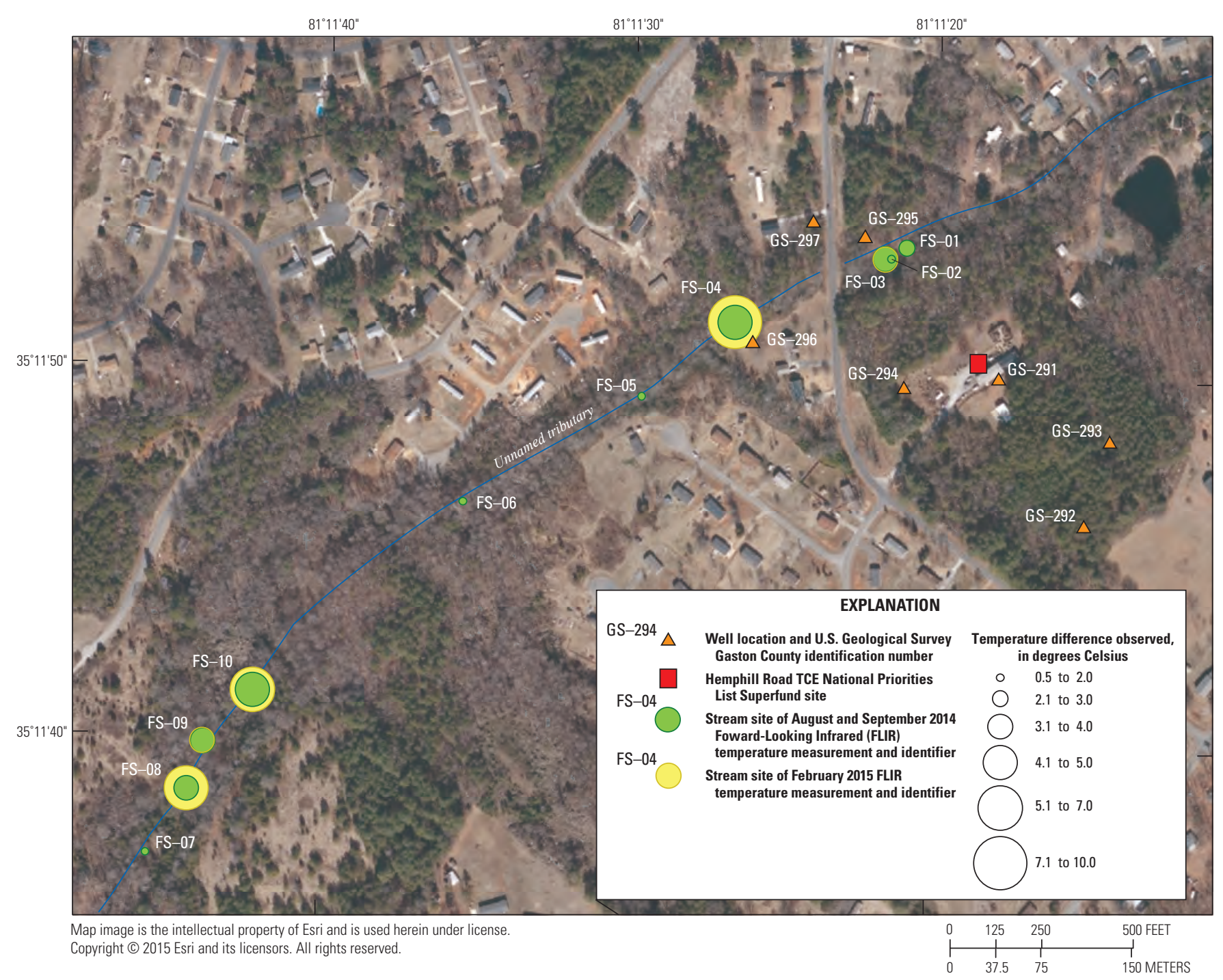

Figure 11. Stream sites with stream surface and bank seepage temperature differences derived from Forward-Looking Infrared camera measurements in August and September 2014 and February 2015 near the Hemphill Road TCE National Priorities List Superfund site, Gastonia, Gaston County, North Carolina.

\section{Summary}

The collection of borehole geophysical logs and thermal imaging data near the Hemphill Road TCE National Priorities List Superfund site was done in an effort to assist the U.S. Environmental Protection Agency in the development of a conceptual groundwater model for the assessment of current contaminant distribution and future migration of contaminants. The effort involved surface geological mapping and borehole geophysical log and image data collection, where more than 600 subsurface features (primarily fracture orientations) were delineated in seven monitoring wells. The data provide information on the general trends of local subsurface features at the sites. Open or primary subsurface fractures were between 65 and $210 \mathrm{ft}$ below land surface. The dominant strike orientations for the primary fractures were $0^{\circ}-20^{\circ}$ (depth ranged from
95 to $108 \mathrm{ft}$ below land surface) and $220^{\circ}-230^{\circ}$ (depth ranged from 119 to $208 \mathrm{ft}$ below land surface) (fig. 6); the median dip angle for the open fractures was $33^{\circ}$.

Also, 10 sites along the nearby creek where groundwater discharge is likely were determined based on temperature differences of the stream surface and seepage from the streambank using thermal imagery. Results from the processed thermal images indicate at least five sites of potential groundwater input into the stream from the streambank. The characterization of subsurface features, as well as possible areas of groundwater discharge will aid in the construction of a conceptual groundwater model and the understanding of contaminant migration for the study area. 


\section{Acknowledgments}

The authors would like to thank Laura Gurley, Brad Huffman, and Erik Staub of the U.S. Geological Survey for their assistance in the collection of geophysical logs. Appreciation is also extended to U.S. Geological Survey colleague reviewers, Kristen McSwain and Eve Kuniansky for technical review of the report data.

\section{References Cited}

Advanced Logic Technology, 2010, WellCad ${ }^{\circledR}$ - The composite log package: Advanced Logic Technology, accessed February 2013 at http://www.alt.lu/wellcad.htm. [Also available at http://www.alt.lu/software.htm.]

Antolino, D.J., and Chapman, M.J., 2017, Geophysical logging and thermal imaging at the Hemphill Road TCE NPL Superfund site near Gastonia, North Carolina: U.S. Geological Survey data release, accessed February 2017 at https://doi.org/10.5066/F71R6NPM.

Chapman, M.J., Bolich, R.E., and Huffman, B.A., 2005, Hydrogeologic setting, ground-water flow, and ground-water quality at the Lake Wheeler Road research station, 2001-03, North Carolina Piedmont and Mountains Resource Evaluation Program: U.S. Geological Survey Scientific Investigations Report 2005-5166, 85 p. [Also available at https://pubs.usgs.gov/sir/2005/5166/.]

Day-Lewis, F.D., Johnson, C.D., Paillet, F.L., and Halford, K.J., 2011a, A computer program for flow-log analysis of single holes (FLASH): Groundwater, v. 49, no. 6, p. 926-931. [Also available at https://doi.org/10.1111/j.1745-6584.2011.00798.x.]

Day-Lewis, F.D., Johnson, C. D., Paillet, F.L., and Halford, K.J, 2011, FLASH-A computer program for flow-log analysis of single holes (ver. 1.0): U.S. Geological Survey software release. [Also available https://doi.org/10.5066/F7319SZC.]

Deitchman, R.S., and Loheide, S.P., II, 2009, Ground-based thermal imaging of groundwater flow processes at the seepage face: Geophysical Research Letters, v. 36, no. 14, L14401. [Also available at https://doi.org/10.1029/2009GL038103.]

Goldsmith, Richard, Milton, D.J., and Horton, J.W., Jr., 1988, Geologic map of the Charlotte 1 degree by 2 degree quadrangle, North Carolina and South Carolina:

U.S. Geological Survey Miscellaneous Investigations Series Map I-1251-E, 1 pl., scale 1:250,000, accessed March 2014 at http://ngmdb.usgs.gov/Prodesc/proddesc_9068.htm.
Heath, R.C., 1980, Basic elements of ground-water hydrology with reference to conditions in North Carolina: U.S. Geological Survey Water-Resources Investigations Open-File Report 80-44, 86 p. [Also available at https://pubs.usgs.gov/of/1980/0044/report.pdf.]

Heath, R.C., 1994, Ground-water recharge in North Carolina: Raleigh, North Carolina Department of Environment, Health, and Natural Resources, Groundwater Section, Open-File Report, 52 p.

Hibbard, J.P., Stoddard, E.F., Secor, D.T., and Dennis, A.J., 2002, The Carolina Zone - Overview of Neoproterozoic to Early Paleozoic peri-Gondwanan terranes along the eastern flank of the southern Appalachians: Earth Science Reviews, v. 57, nos. 3-4, p. 299-339. [Also available at http://dx.doi.org/10.1016/S0012-8252(01)00079-4.]

Horton, J.W., Jr., 2008, Geologic map of the Kings Mountain and Grover quadrangles, Cleveland and Gaston Counties, North Carolina, and Cherokee and York Counties, South Carolina: U.S. Geological Survey Scientific Investigations Map 2981, 1 sheet, scale 1:24,000, with 15-p. pamphlet. [Also available at https://pubs.usgs.gov/sim/2981/.]

Horton, J.W., Jr., Butler, J.R., and Milton, D.M., eds., 1981, Geological investigations of the Kings Mountain belt and adjacent areas in the Carolinas: Carolina Geological Society Field Trip Guidebook 1981, 257p., accessed March 2014 at http://carolinageologicalsociety.org/CGS/1980s_files/ gb\%201981.pdf.

Huffman, B.A., Pfeifle, C.A., Chapman, M.J., Bolich, R.E., Campbell, T.R., Geddes, D.J., Jr., and Pippin, C.G., 2006, Compilation of water-resources data and hydrogeologic setting for four research stations in the Piedmont and Blue Ridge Physiographic Provinces of North Carolina, 2000-2004: U.S. Geological Survey Open-File Report 2006-1168, 102 p., accessed March 2014 at https://pubs.usgs.gov/of/2006/1168/.

J.M. Waller Associates, 2014, Hemphill Road TCE site health and safety plan, 2014: J.M. Waller Associates, 58 p.

McSwain, K.B., Bolich, R.E., and Chapman, M.J., 2013, Hydrogeology, groundwater seepage, nitrate distribution, and flux at the Raleigh hydrogeologic research station, Wake County, North Carolina, 2005-2007: U.S. Geological Survey Scientific Investigations Report 2013-5041, 54 p., accessed March 2014 at https://pubs.usgs.gov/sir/2013/5041/.

McSwain, K.B., Bolich, R.E., Chapman, M.J., and Huffman, B.A., 2009, Water-resources data and hydrogeologic setting at the Raleigh hydrogeologic research station, Wake County, North Carolina, 2005-2007: U.S. Geological Survey Open-File Report 2008-1377, 48 p., accessed March 2014 at https://pubs.water.usgs.gov/ofr2008-1377. 
National Oceanic and Atmospheric Administration, 2015, Magnetic field calculators: National Oceanic and Atmospheric Administration, National Centers for Environmental Information website, accessed June 2015 at https://www.ngdc.noaa.gov/geomag-web/\#declination.

North Carolina Geological Survey, 1985, Geologic map of North Carolina: Raleigh, North Carolina Geological Survey, scale 1:500,000.

Pandey, Priyanka, Gleeson, Tom, and Baraer, Michel, 2013, Toward quantifying discrete groundwater discharge from frozen seepage faces using thermal infrared images: Geophysical Research Letters, v. 40, no. 1, p. 123-127. [Also available at https://doi.org/10.1029/2012GL054315.]

Pippin, C.G., Chapman, M.J., Huffman, B.A., Heller, M.J., and Schelgel, M.E., 2008, Hydrogeologic setting, ground-water flow, and ground-water quality at the Langtree Peninsula research station, Iredell County, North Carolina, 2000-2005: U.S. Geological Survey Scientific Investigations Report 2008-5055, 89 p., accessed March 2014 at https://pubs.water.usgs.gov/sir2008-5055.
Srivastav, S.K., Lubexynski, M.W., and Biyani, A.K., 2007, Upscaling of transmissivity, derived from specific capacity-A hydrogeomorphological approach applied to the Doon Valley aquifer system in India: Hydrogeology Journal, v. 15, no. 7, p. 1251-1264. [Also available at https://doi.org/10.1007/s10040-007-0207-8.]

U.S. Environmental Protection Agency, 2013, HRS Documentation Record, Hemphill Road TCE: U.S. Environmental Protection Agency, 36 p.

U.S. Environmental Protection Agency, 2016, Table of regulated drinking water contaminants: U.S. Environmental Protection Agency website, accessed December 2016 at https://www.epa.gov/ground-water-and-drinking-water/ table-regulated-drinking-water-contaminants 

Appendix 1. Borehole Geophysical Image Logs Showing Orientations of Subsurface Structural Features 


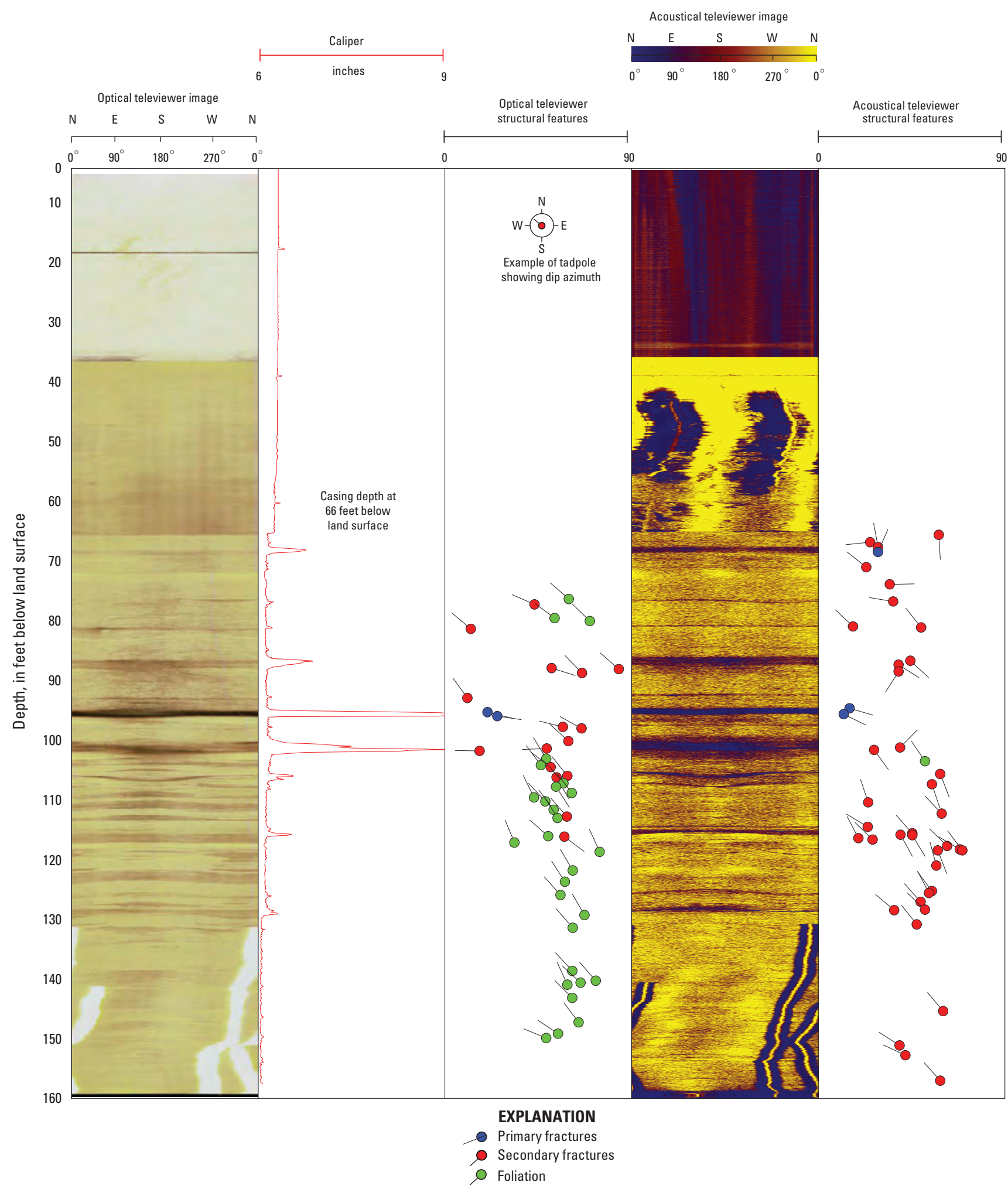

Figure 1-1. Optical televiewer image and structural orientations of subsurface features in well GS-291, near the Hemphill Road TCE National Priorities List Superfund site, Gastonia, Gaston County, North Carolina. 


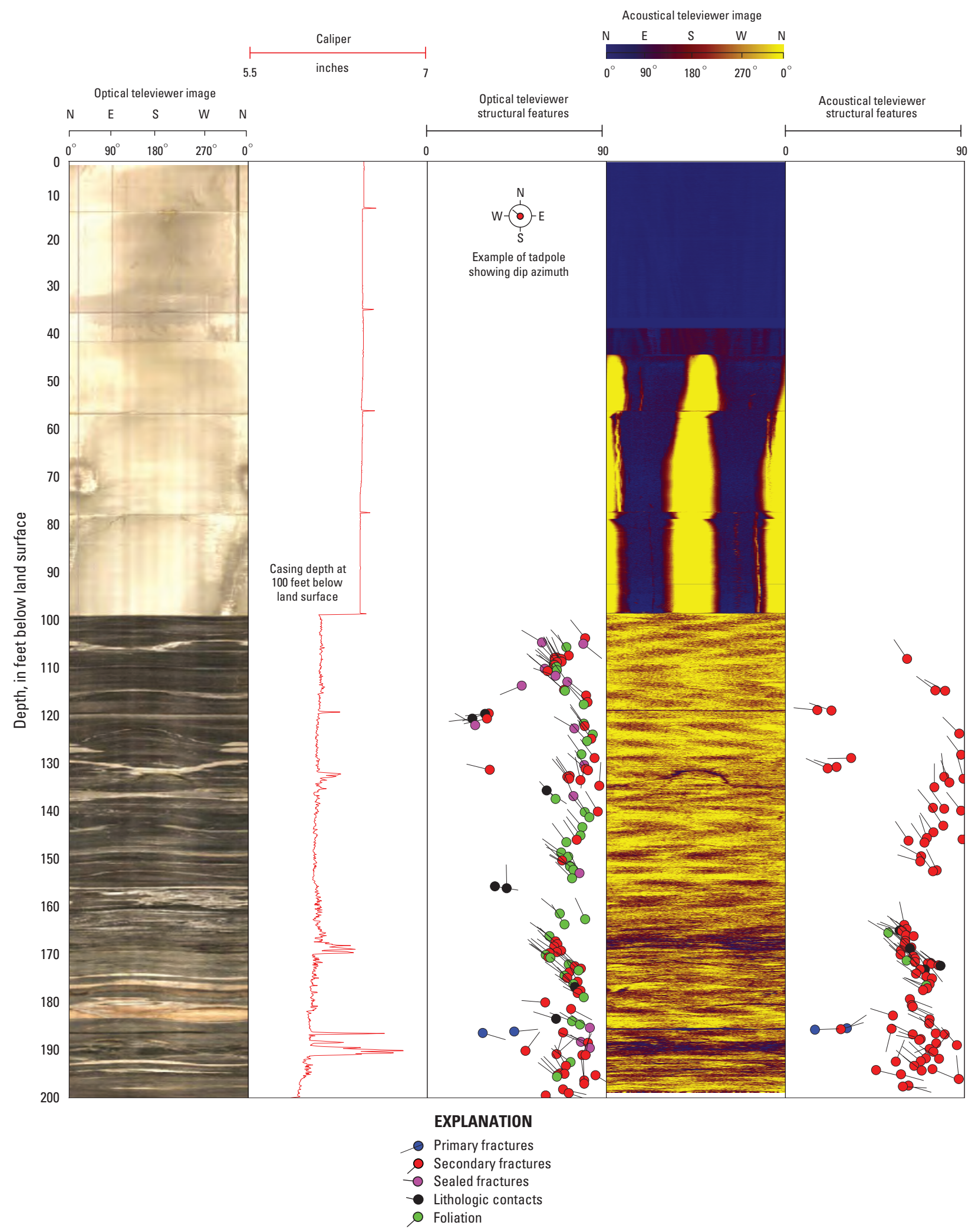

Figure 1-2. Optical televiewer image and structural orientations of subsurface features in well GS-292, near the Hemphill Road TCE National Priorities List Superfund site, Gastonia, Gaston County, North Carolina. 


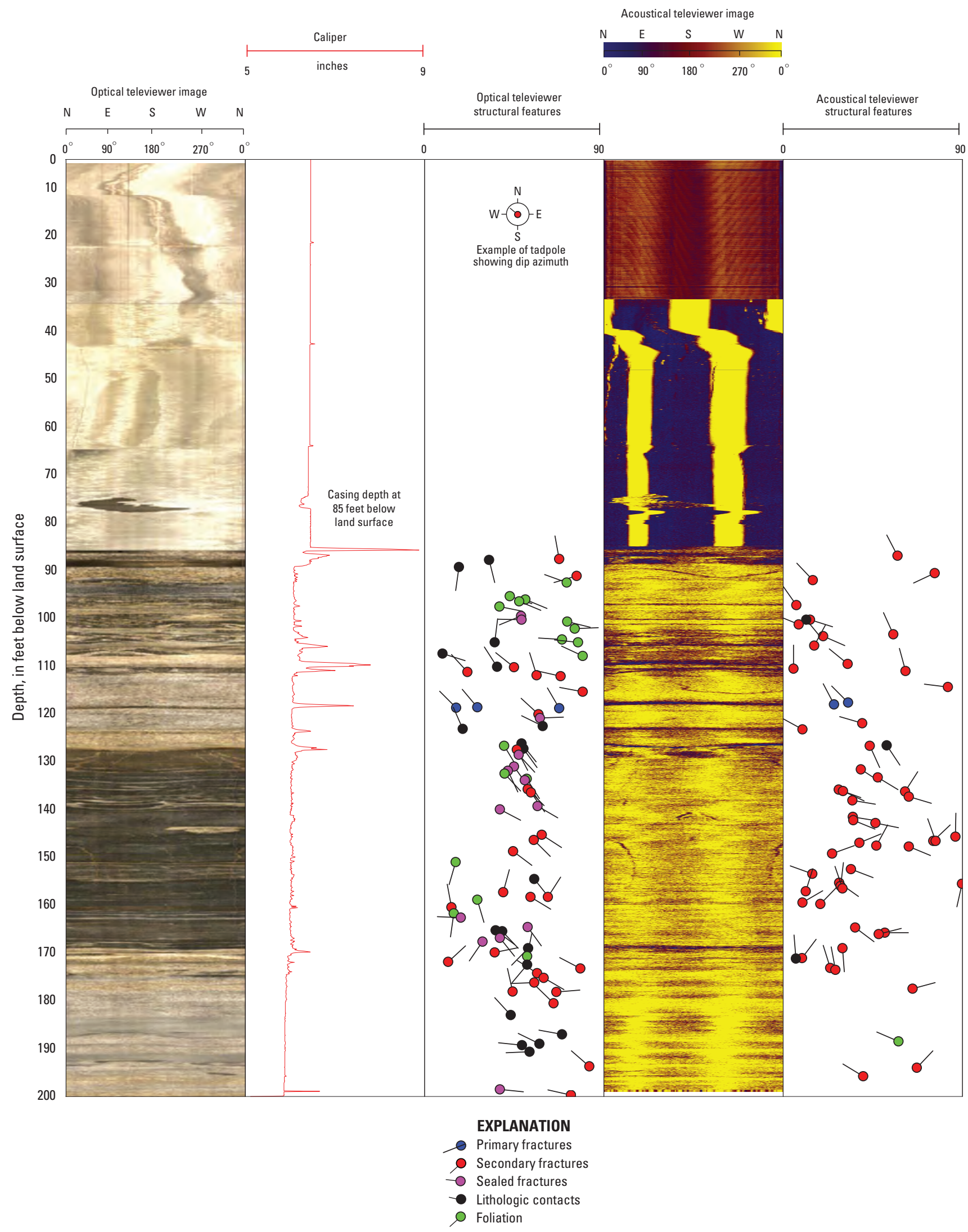

Figure 1-3. Optical televiewer image and structural orientations of subsurface features in well GS-293, near the Hemphill Road TCE National Priorities List Superfund site, Gastonia, Gaston County, North Carolina. 


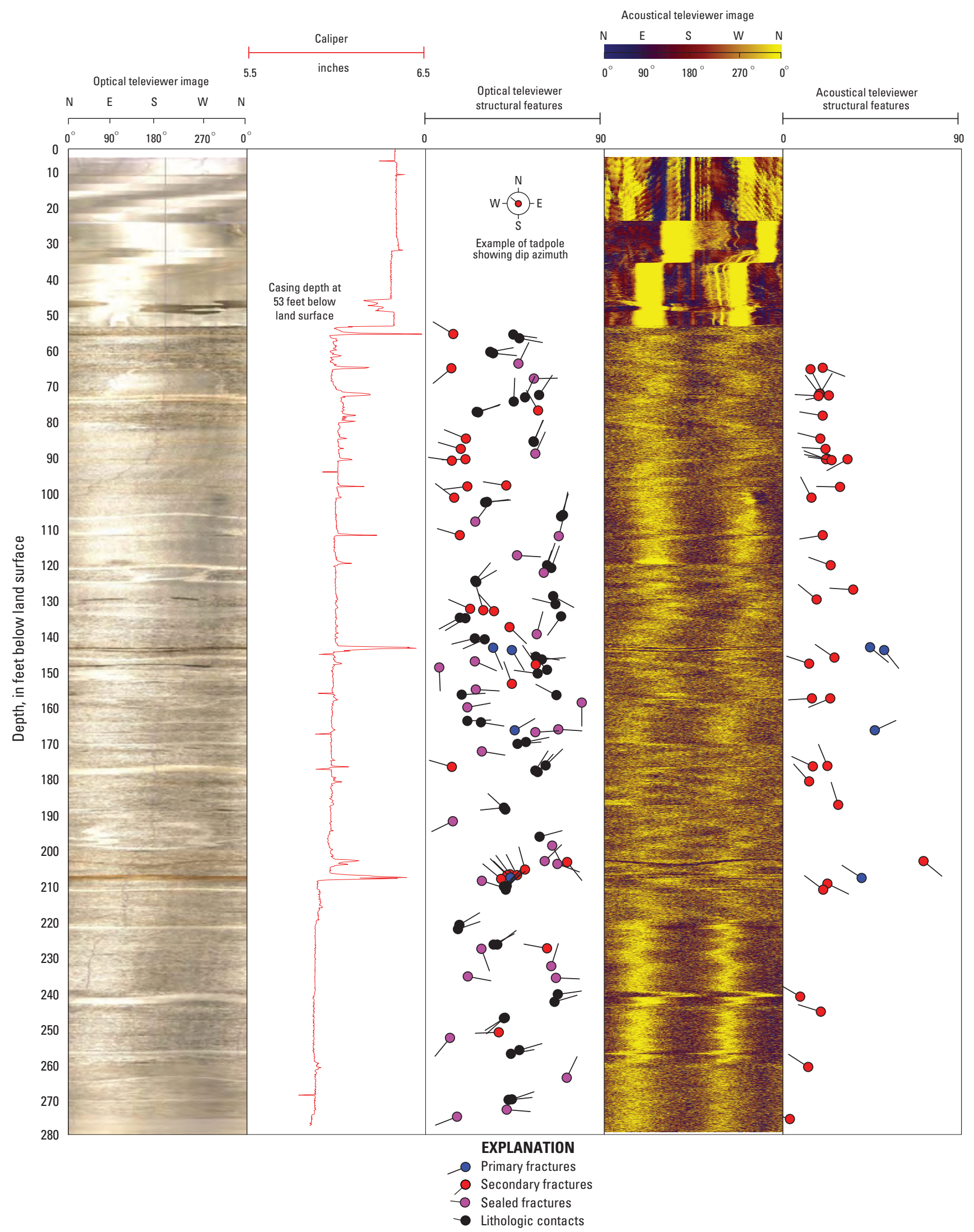

Figure 1-4. Optical televiewer image and structural orientations of subsurface features in well GS-294, near the Hemphill Road TCE National Priorities List Superfund site, Gastonia, Gaston County, North Carolina. 


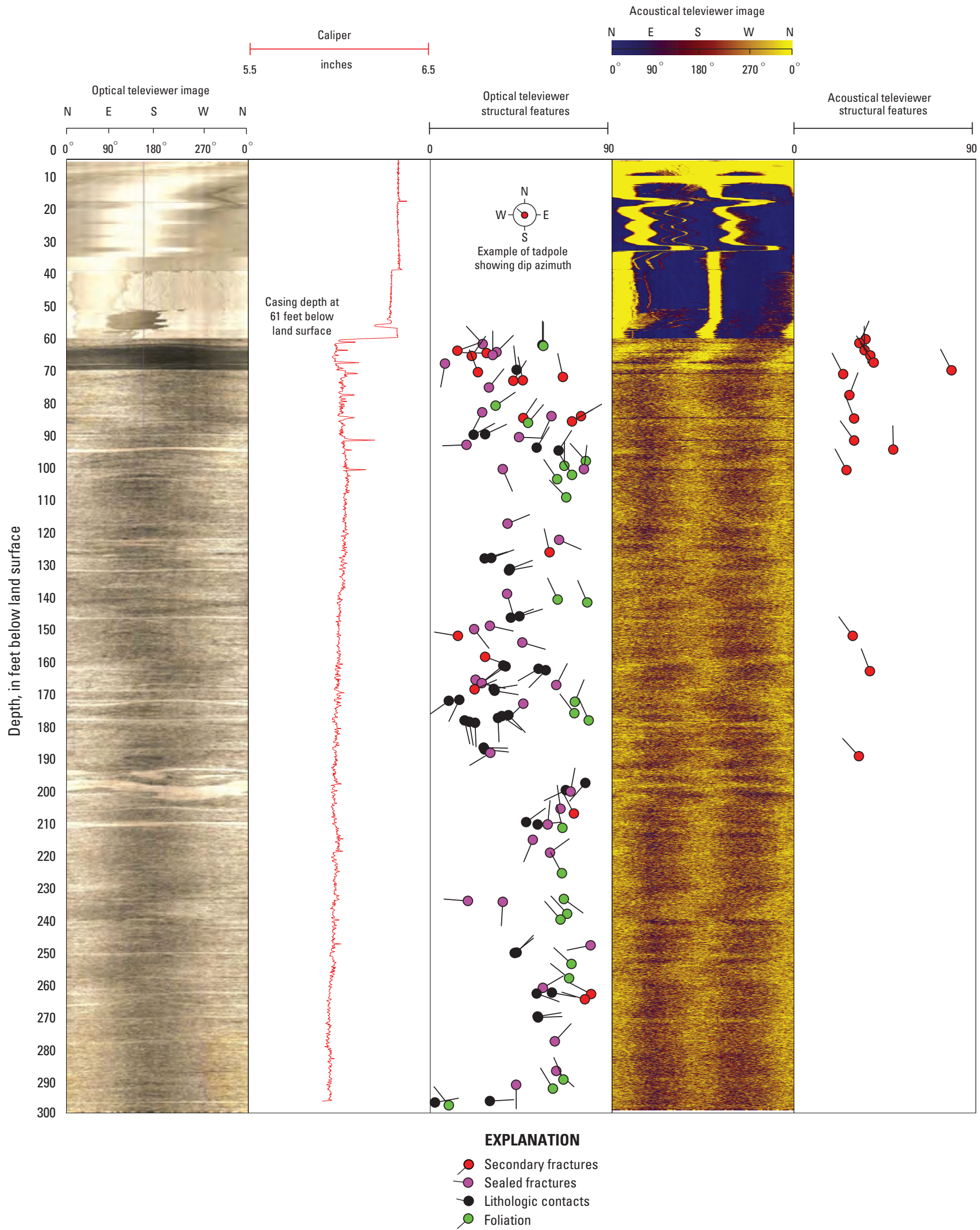

Figure 1-5. Optical televiewer image and structural orientations of subsurface features in well GS-295, near the Hemphill Road TCE National Priorities List Superfund site, Gastonia, Gaston County, North Carolina. 


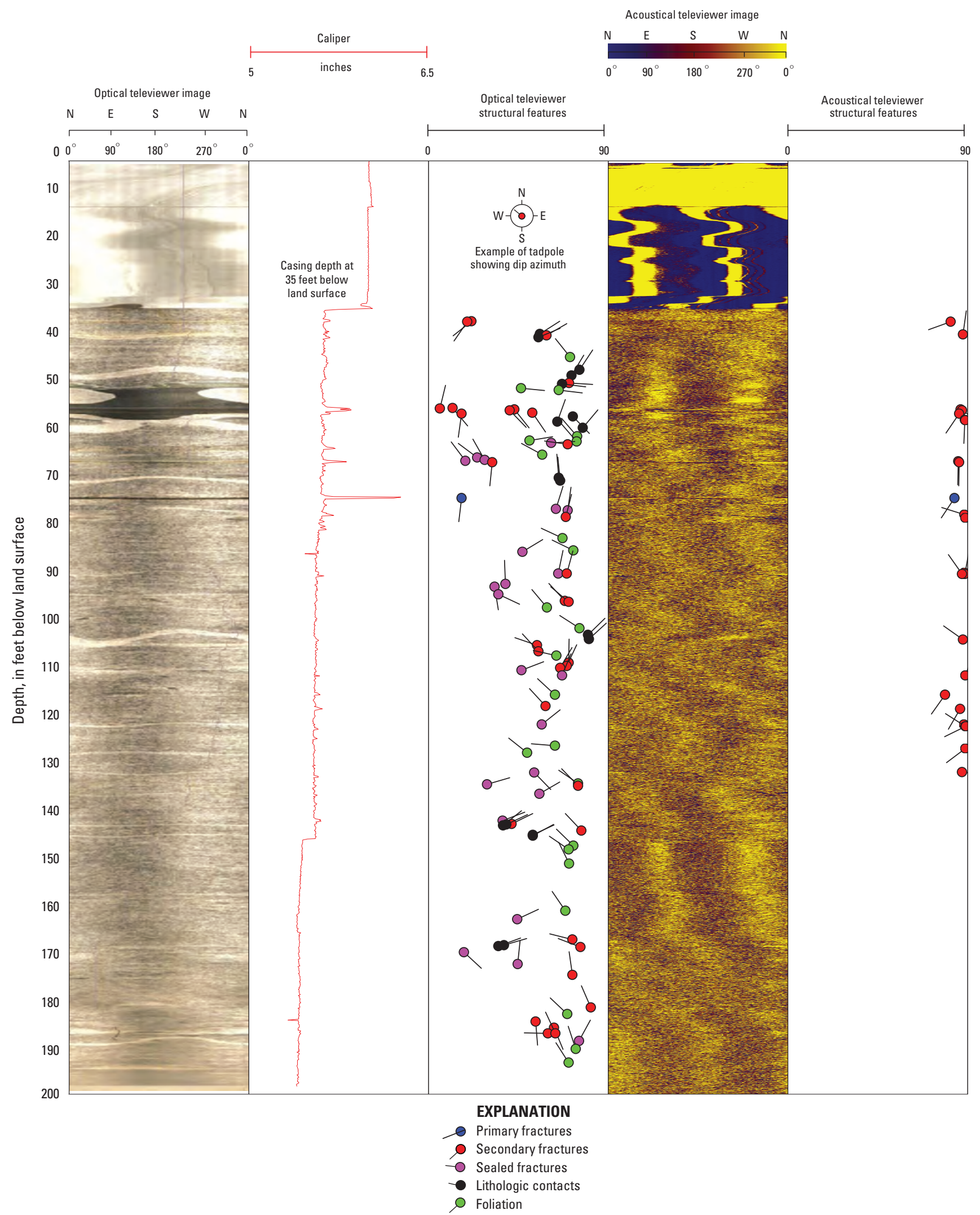

Figure 1-6. Optical televiewer image and structural orientations of subsurface features in well GS-296, near the Hemphill Road TCE National Priorities List Superfund site, Gastonia, Gaston County, North Carolina. 


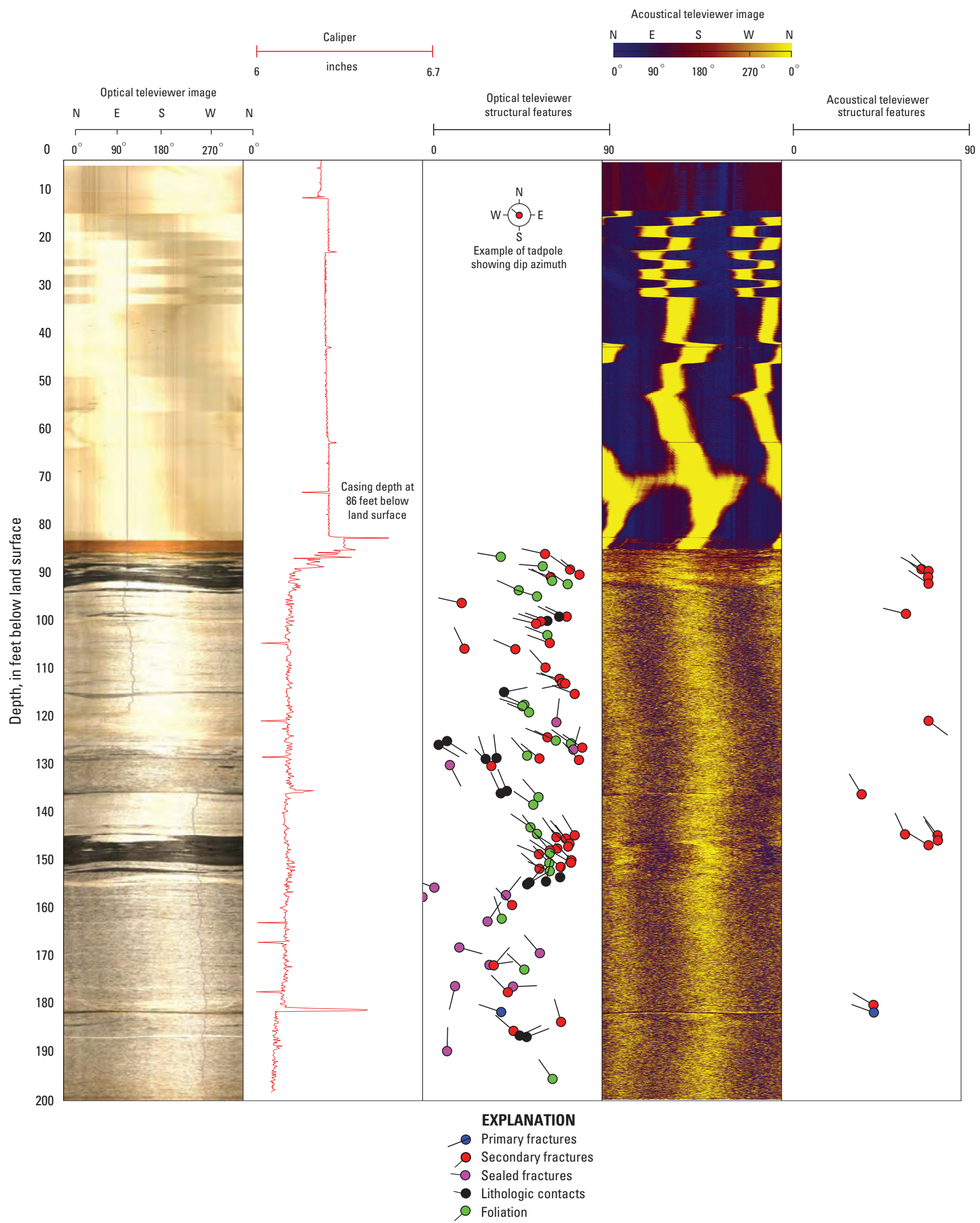

Figure 1-7. Optical televiewer image and structural orientations of subsurface features in well GS-297, near the Hemphill Road TCE National Priorities List Superfund site, Gastonia, Gaston County, North Carolina. 
Appendix 2. Borehole Geophysical Logs Showing Depth of Fracture Zones and Borehole Flow 


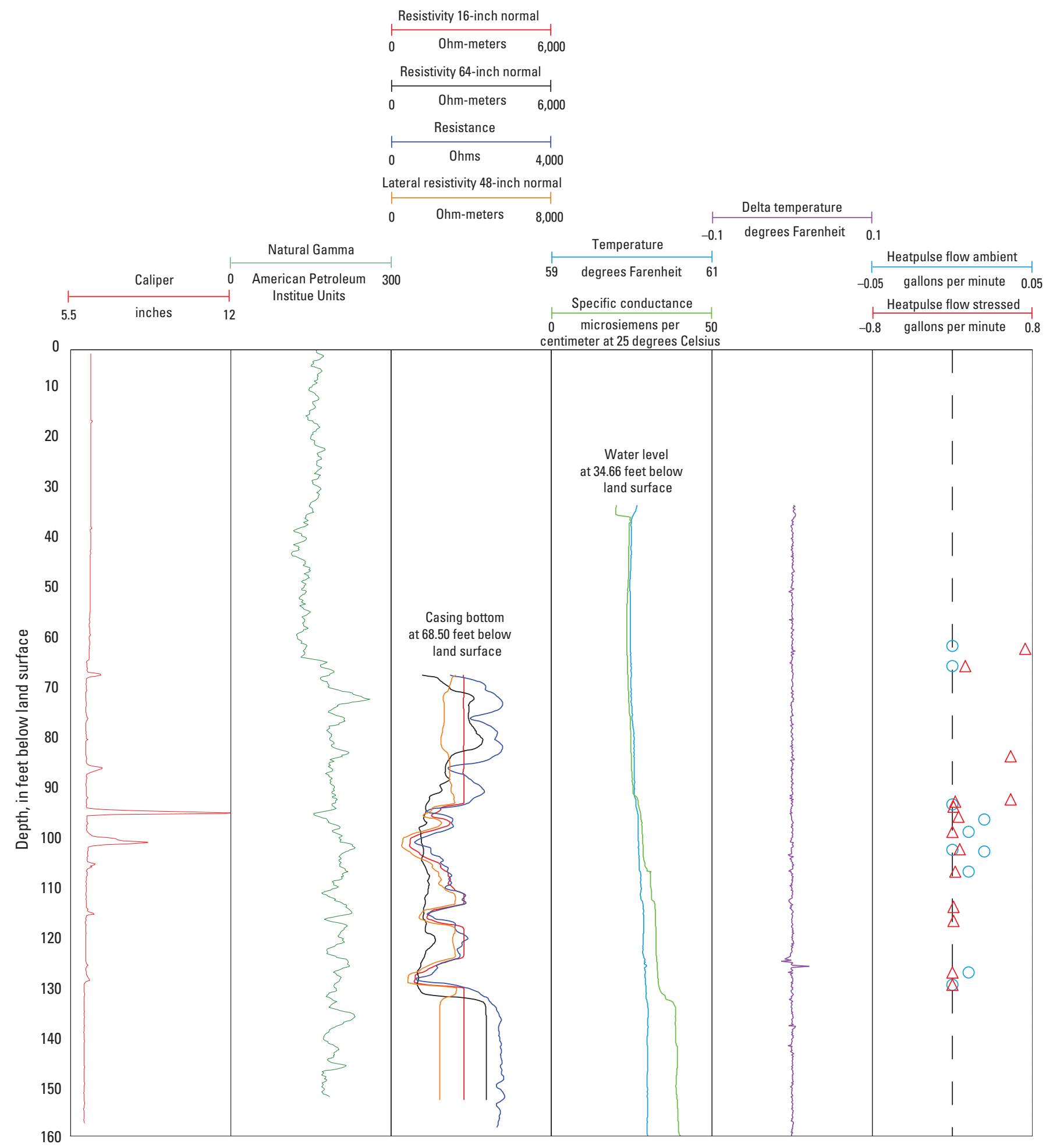

Figure 2-1. Borehole geophysical logs showing depth of fracture zones and borehole flow in well GS-291, near the Hemphill Road TCE National Priorities List Superfund site, Gastonia, Gaston County, North Carolina. 


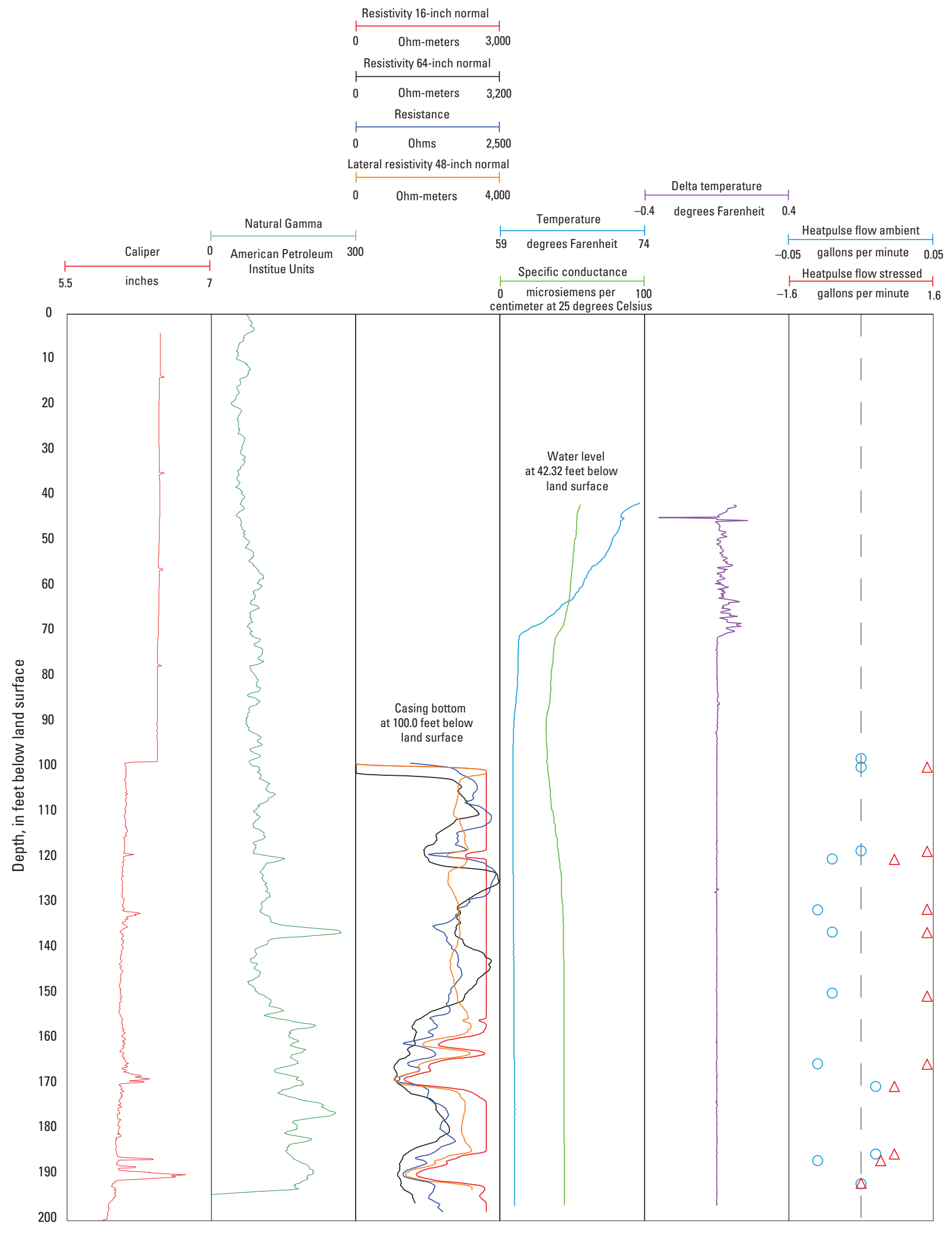

Figure 2-2. Borehole geophysical logs showing depth of fracture zones and borehole flow in well GS-292, near the Hemphill Road TCE National Priorities List Superfund site, Gastonia, Gaston County, North Carolina. 


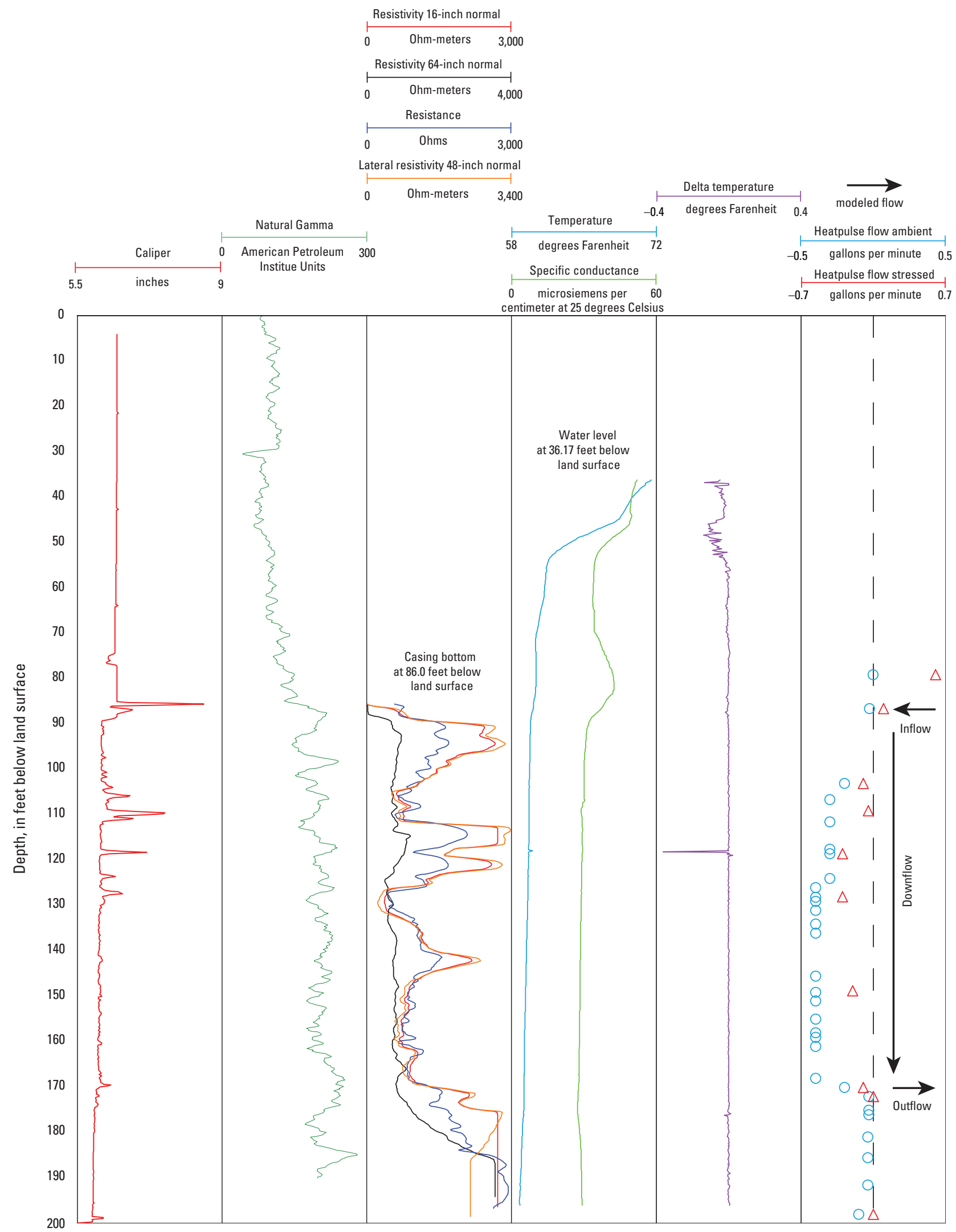

Figure 2-3. Borehole geophysical logs showing depth of fracture zones and borehole flow in well GS-293, near the Hemphill Road TCE National Priorities List Superfund site, Gastonia, Gaston County, North Carolina. 


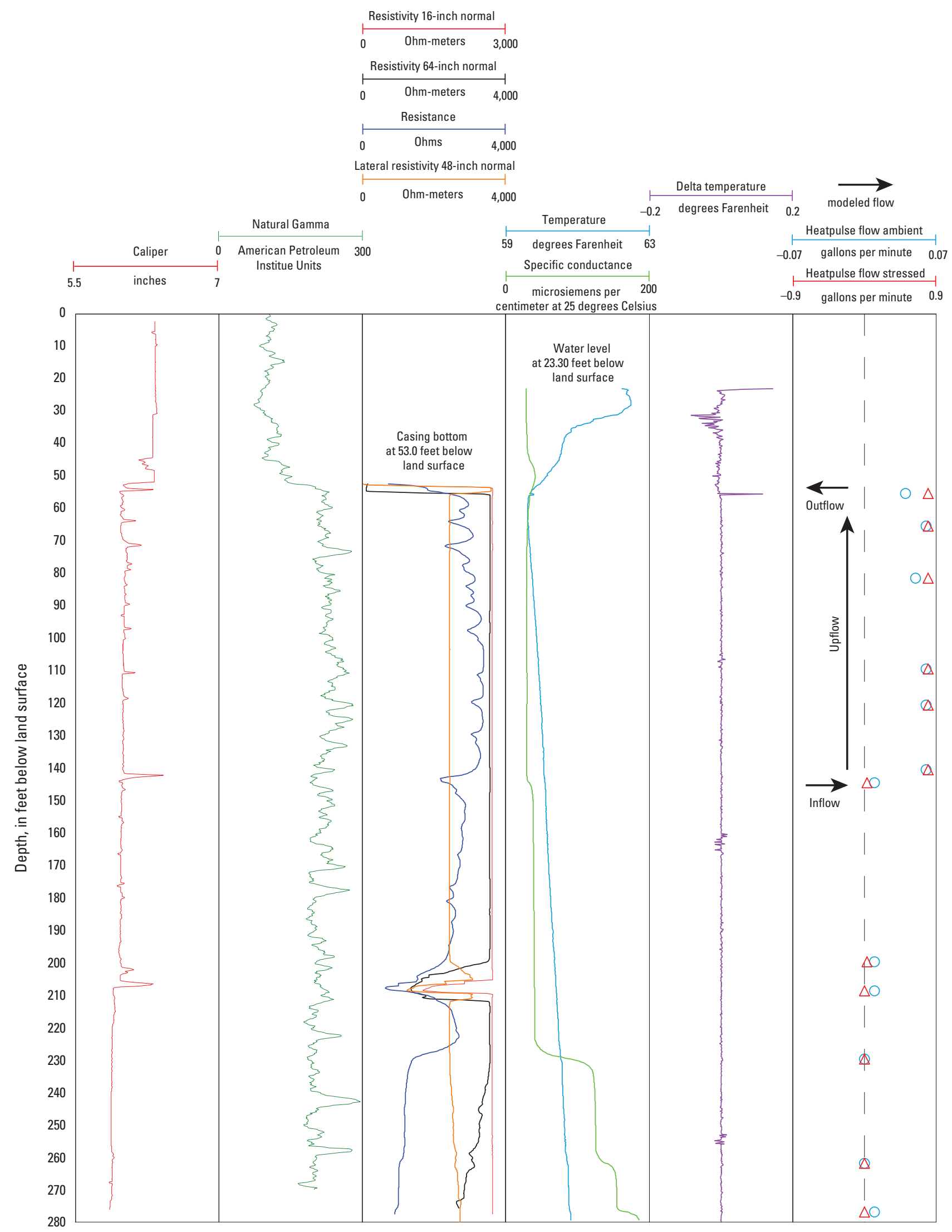

Figure 2-4. Borehole geophysical logs showing depth of fracture zones and borehole flow in well GS-294, near the Hemphill Road TCE National Priorities List Superfund site, Gastonia, Gaston County, North Carolina. 


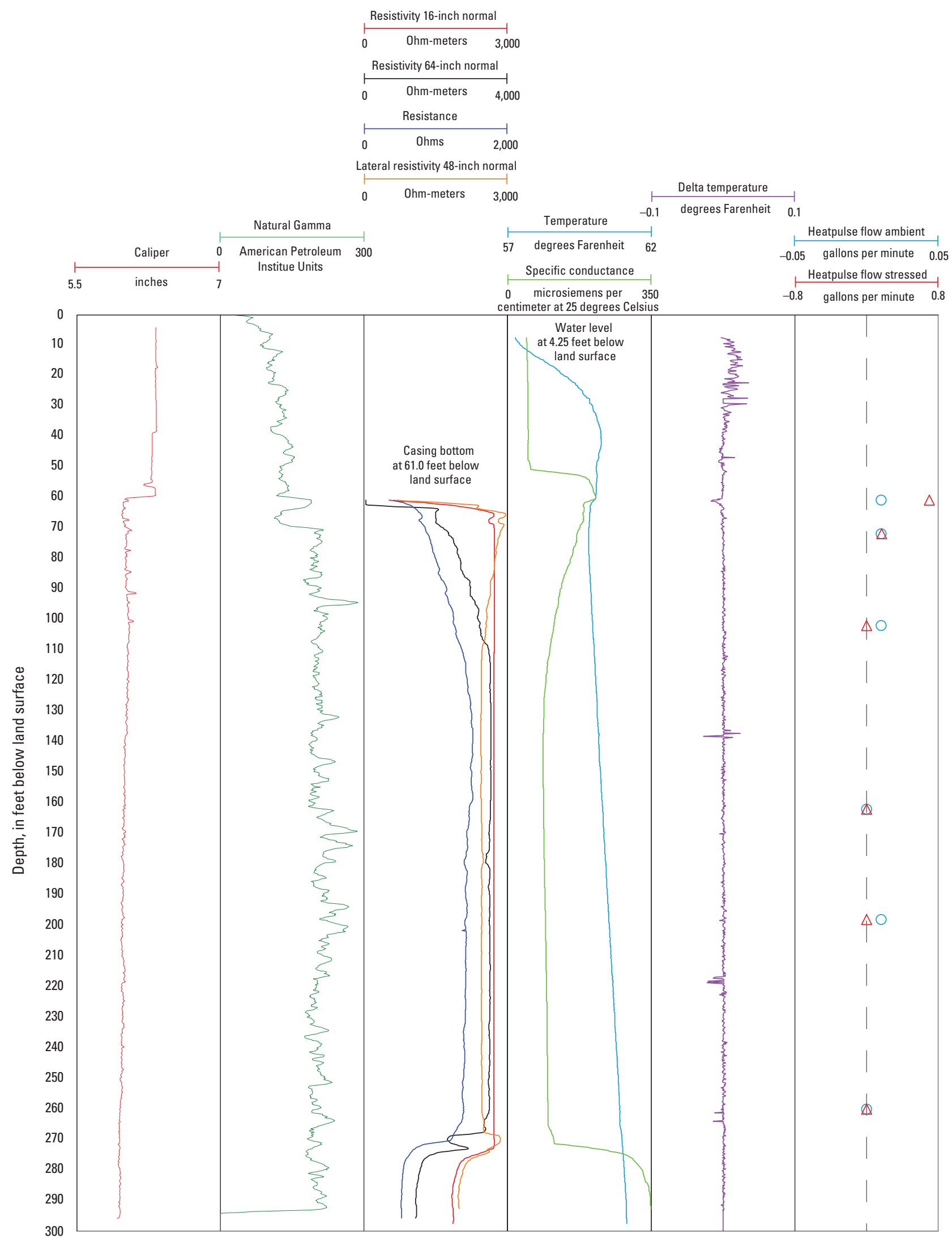

Figure 2-5. Borehole geophysical logs showing depth of fracture zones and borehole flow in well GS-295, near the Hemphill Road TCE National Priorities List Superfund site, Gastonia, Gaston County, North Carolina. 


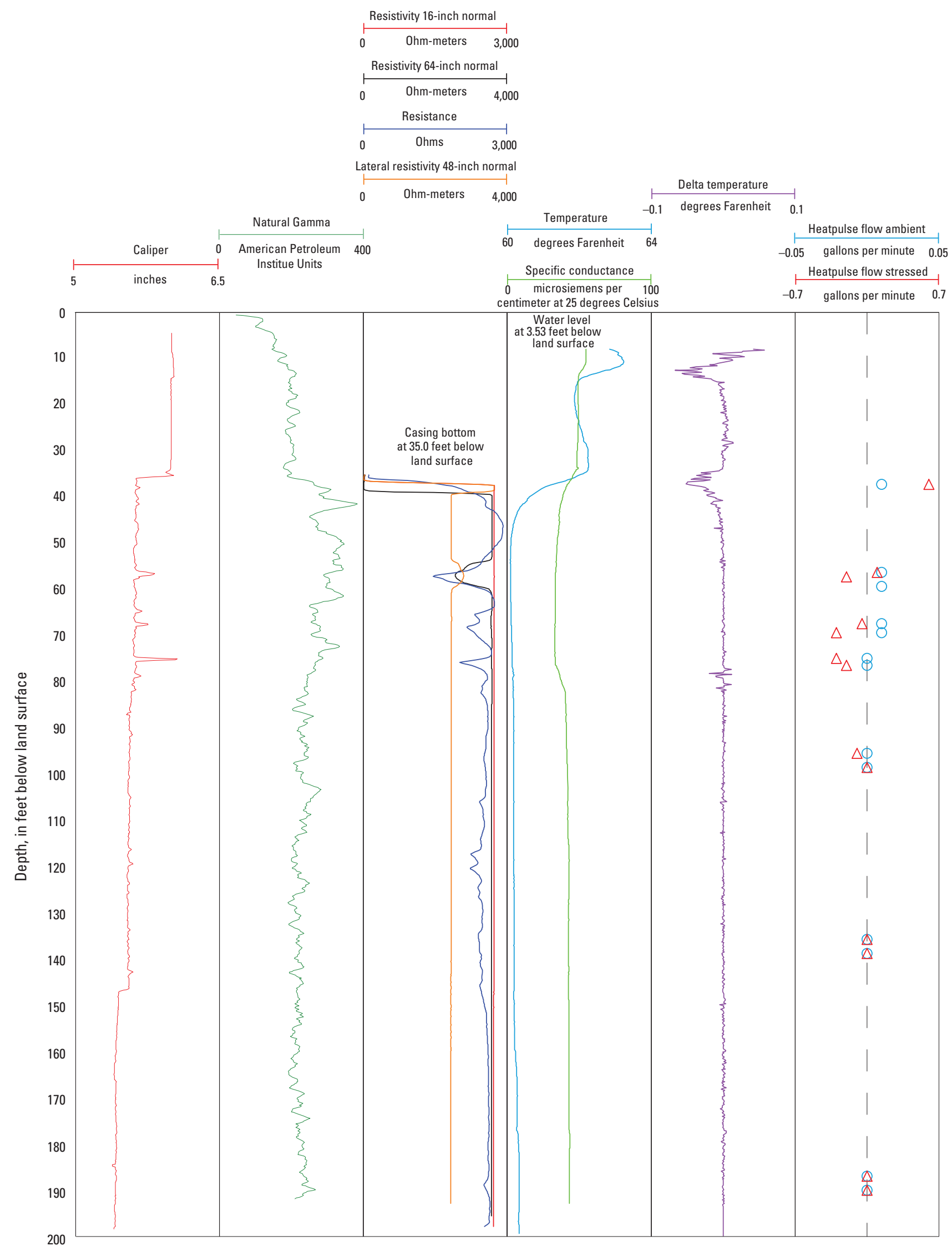

Figure 2-6. Borehole geophysical logs showing depth of fracture zones and borehole flow in well GS-296, near the Hemphill Road TCE National Priorities List Superfund site, Gastonia, Gaston County, North Carolina. 


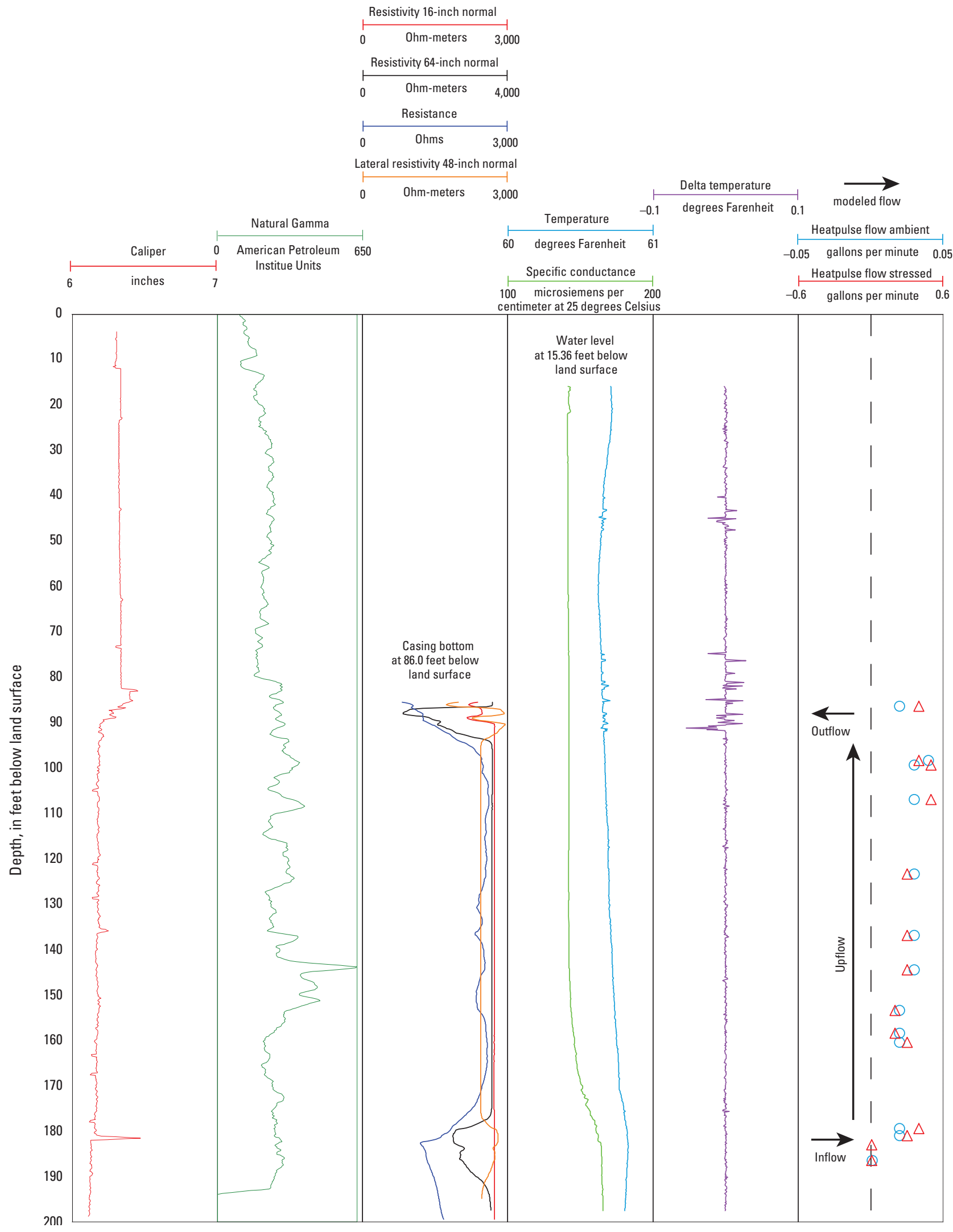

Figure 2-7. Borehole geophysical logs showing depth of fracture zones and borehole flow in well GS-297, near the Hemphill Road TCE National Priorities List Superfund site, Gastonia, Gaston County, North Carolina. 
Appendix 3. Infrared Images Captured by Forward-Looking Infrared Camera at Sites to Measure Stream Surface and Bank Seepage Temperature Differences 


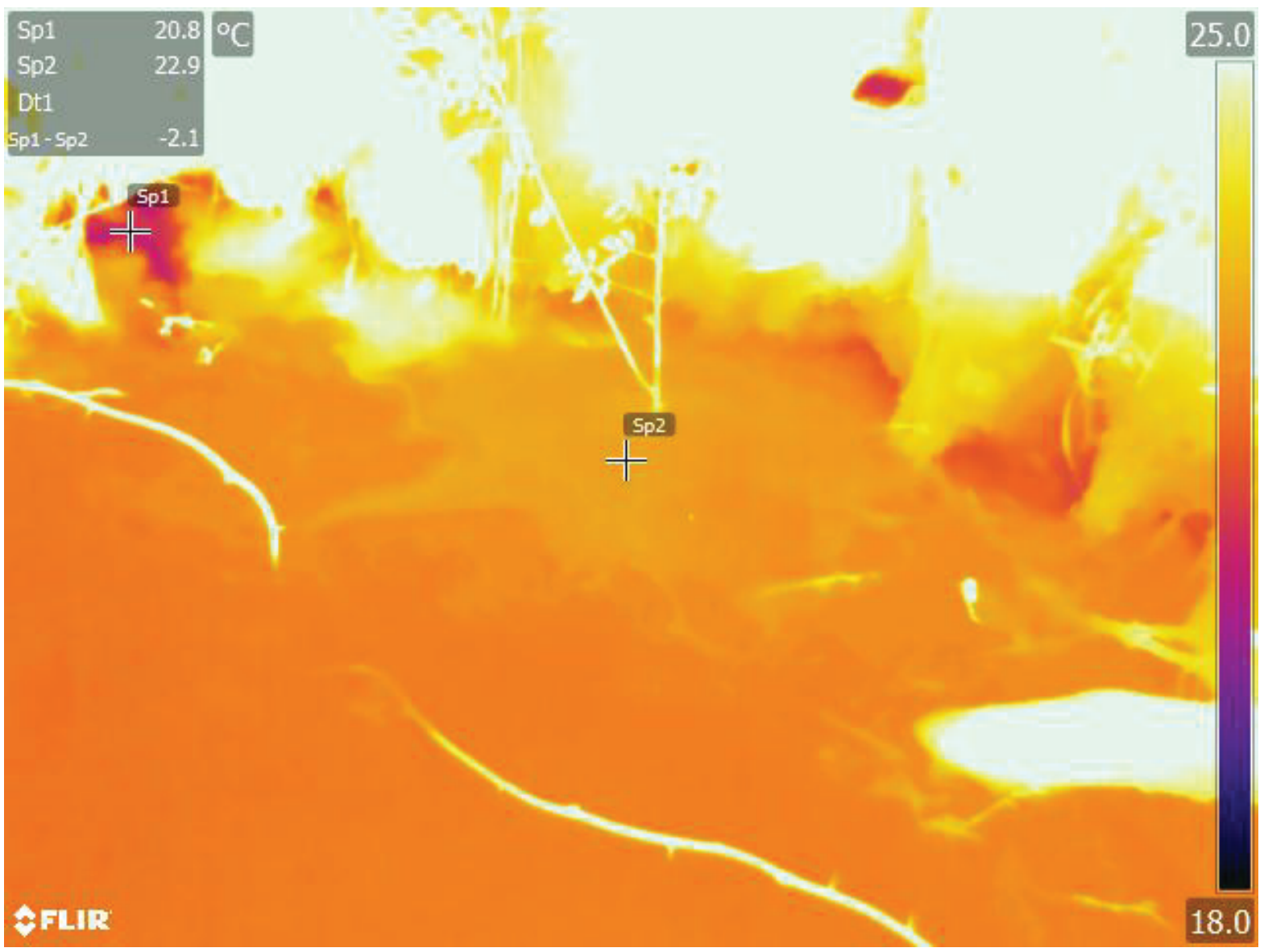

Figure 3-1. Infrared images captured by FLIR camera at site FS-01 to measure stream surface and bank seepage temperature differences in August/September 2014 near the Hemphill Road TCE National Priorities List Superfund site, Gastonia, Gaston County, North Carolina FS-01 to measure stream surface and bank seepage temperature differences in August/ September 2014 near the Hemphill Road TCE National Priorities List Superfund site, Gastonia, Gaston County, North Carolina. 


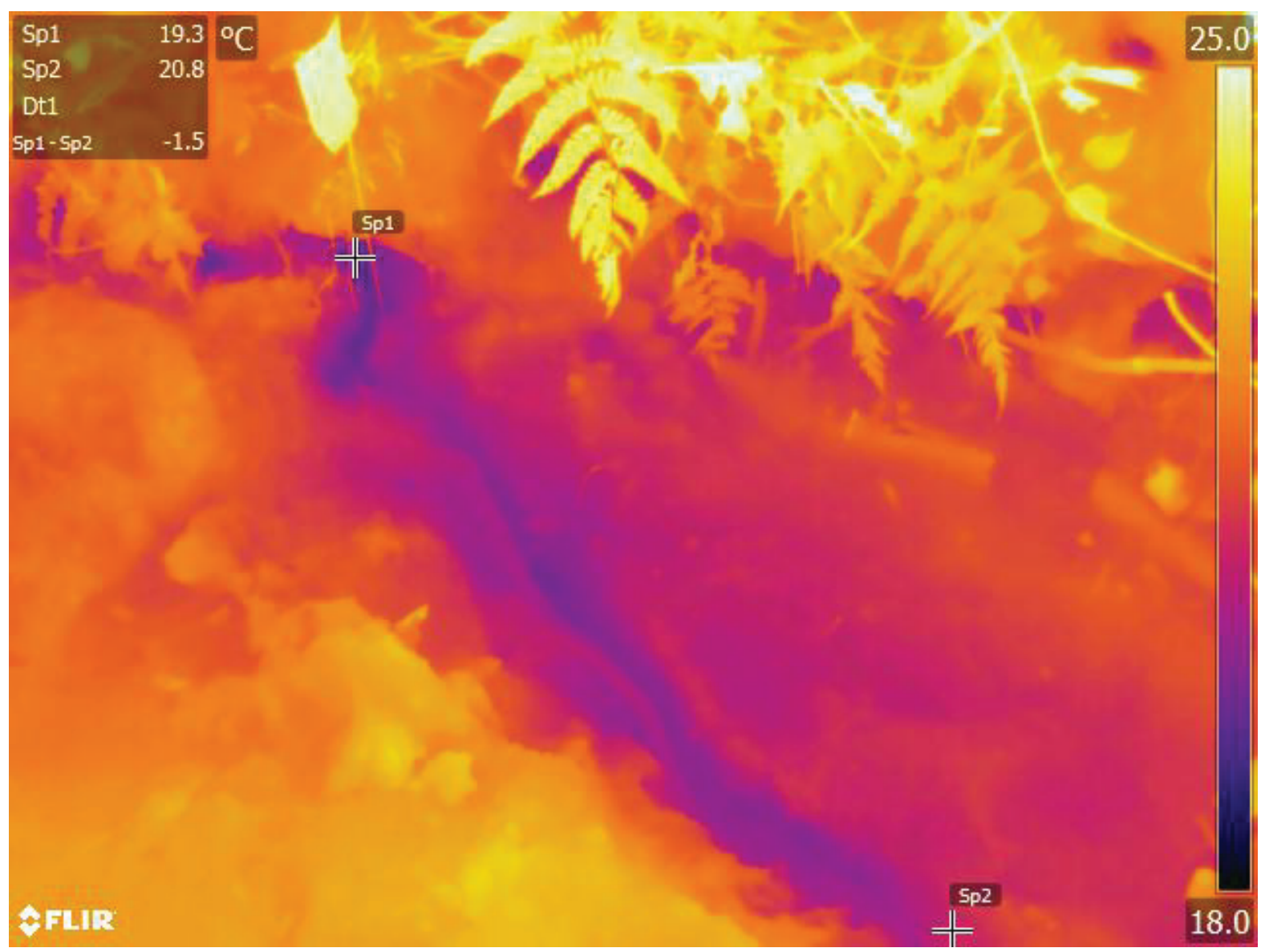

Figure 3-2. Infrared images captured by FLIR camera at site FS-02 to measure stream surface and bank seepage temperature differences in August/September 2014 near the Hemphill Road TCE National Priorities List Superfund site, Gastonia, Gaston County, North Carolina FS-01 to measure stream surface and bank seepage temperature differences in August/ September 2014 near the Hemphill Road TCE National Priorities List Superfund site, Gastonia, Gaston County, North Carolina. 


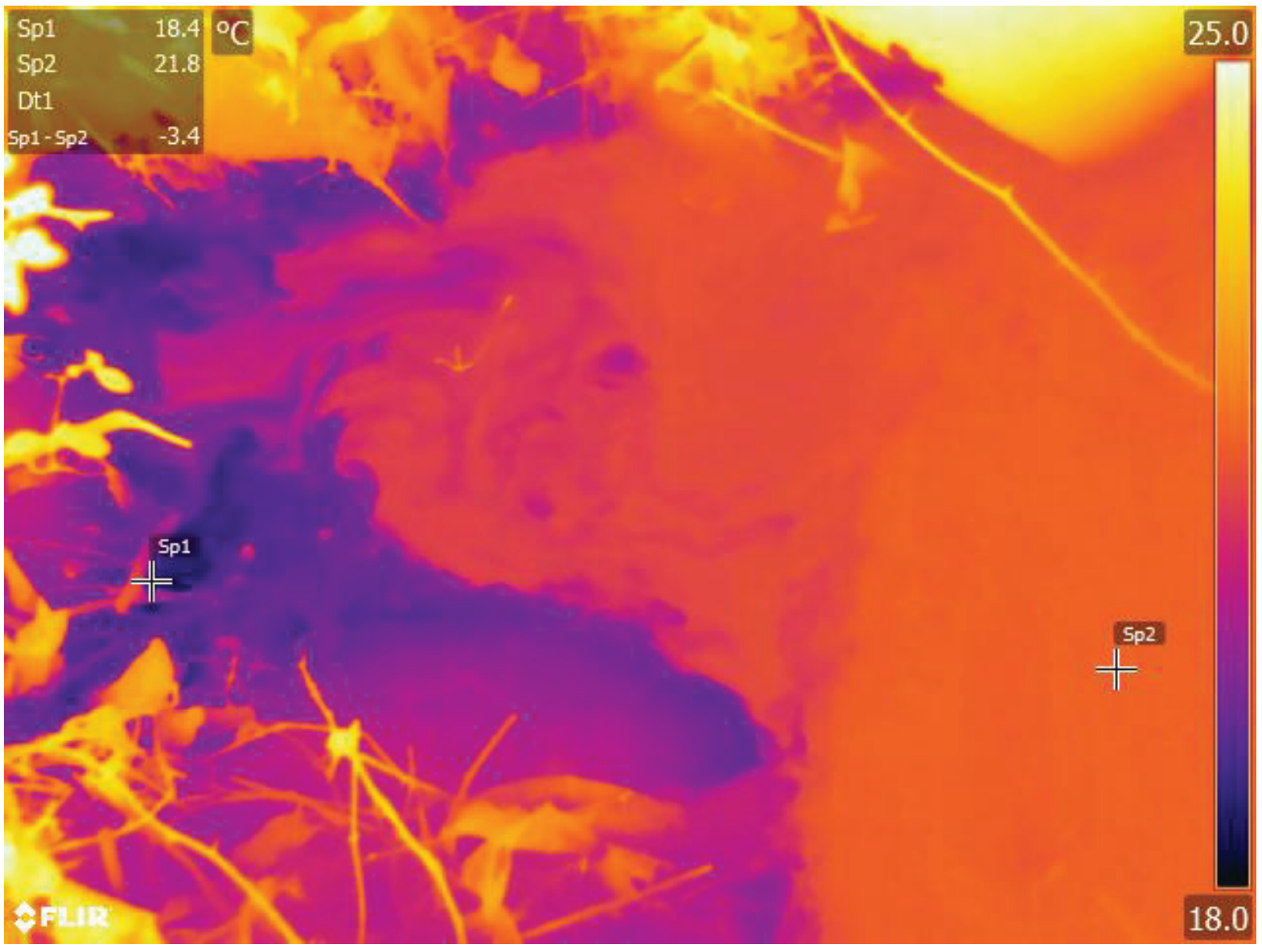

Figure 3-3. Infrared images captured by FLIR camera at site FS-03 to measure stream surface and bank seepage temperature differences in August/September 2014 near the Hemphill Road TCE National Priorities List Superfund site, Gastonia, Gaston County, North Carolina FS-01 to measure stream surface and bank seepage temperature differences in August/ September 2014 near the Hemphill Road TCE National Priorities List Superfund site, Gastonia, Gaston County, North Carolina. 


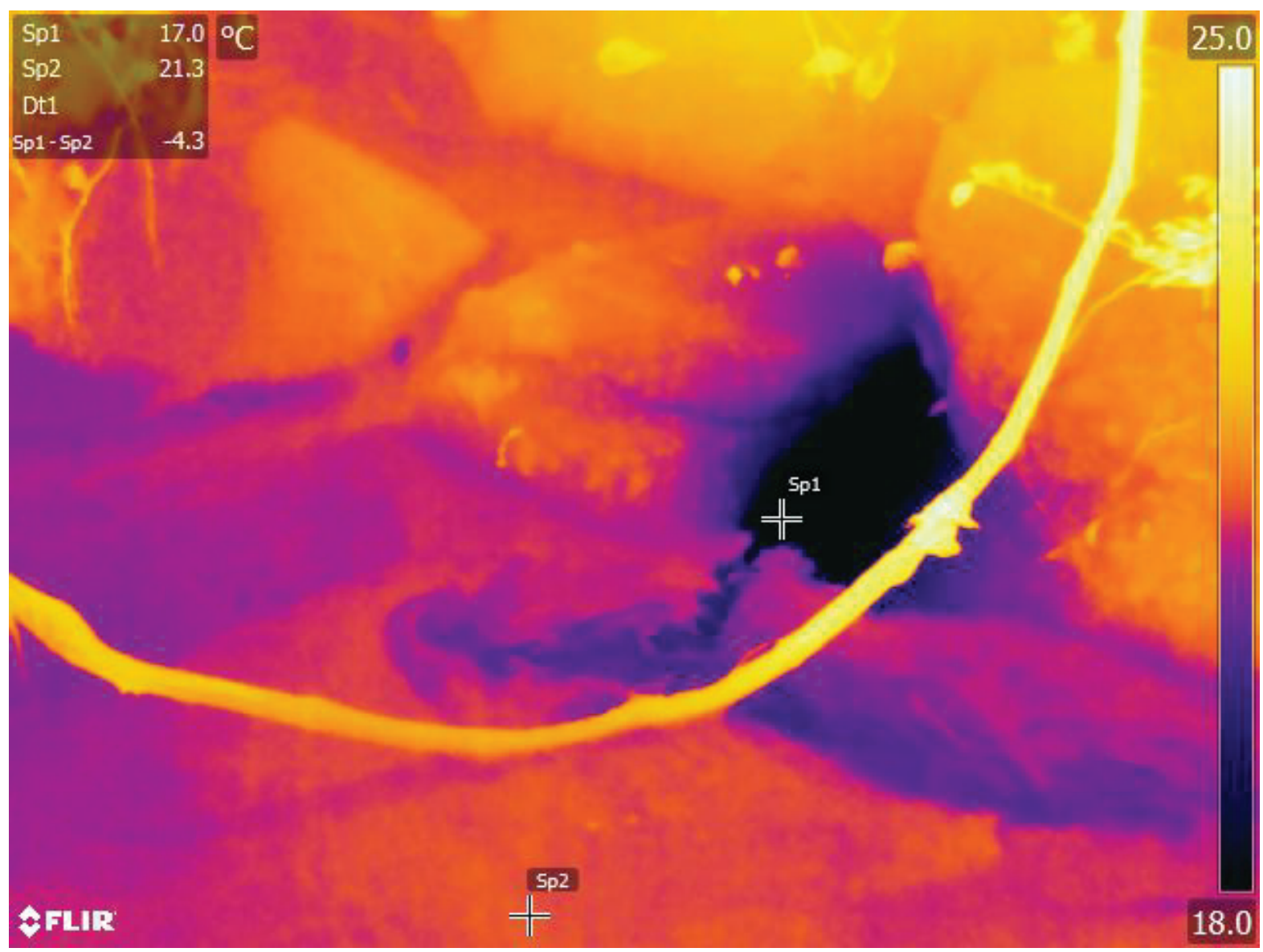

Figure 3-4. Infrared images captured by FLIR camera at site FS-04 to measure stream surface and bank seepage temperature differences in August/September 2014 near the Hemphill Road TCE National Priorities List Superfund site, Gastonia, Gaston County, North Carolina FS-01 to measure stream surface and bank seepage temperature differences in August/ September 2014 near the Hemphill Road TCE National Priorities List Superfund site, Gastonia, Gaston County, North Carolina. 


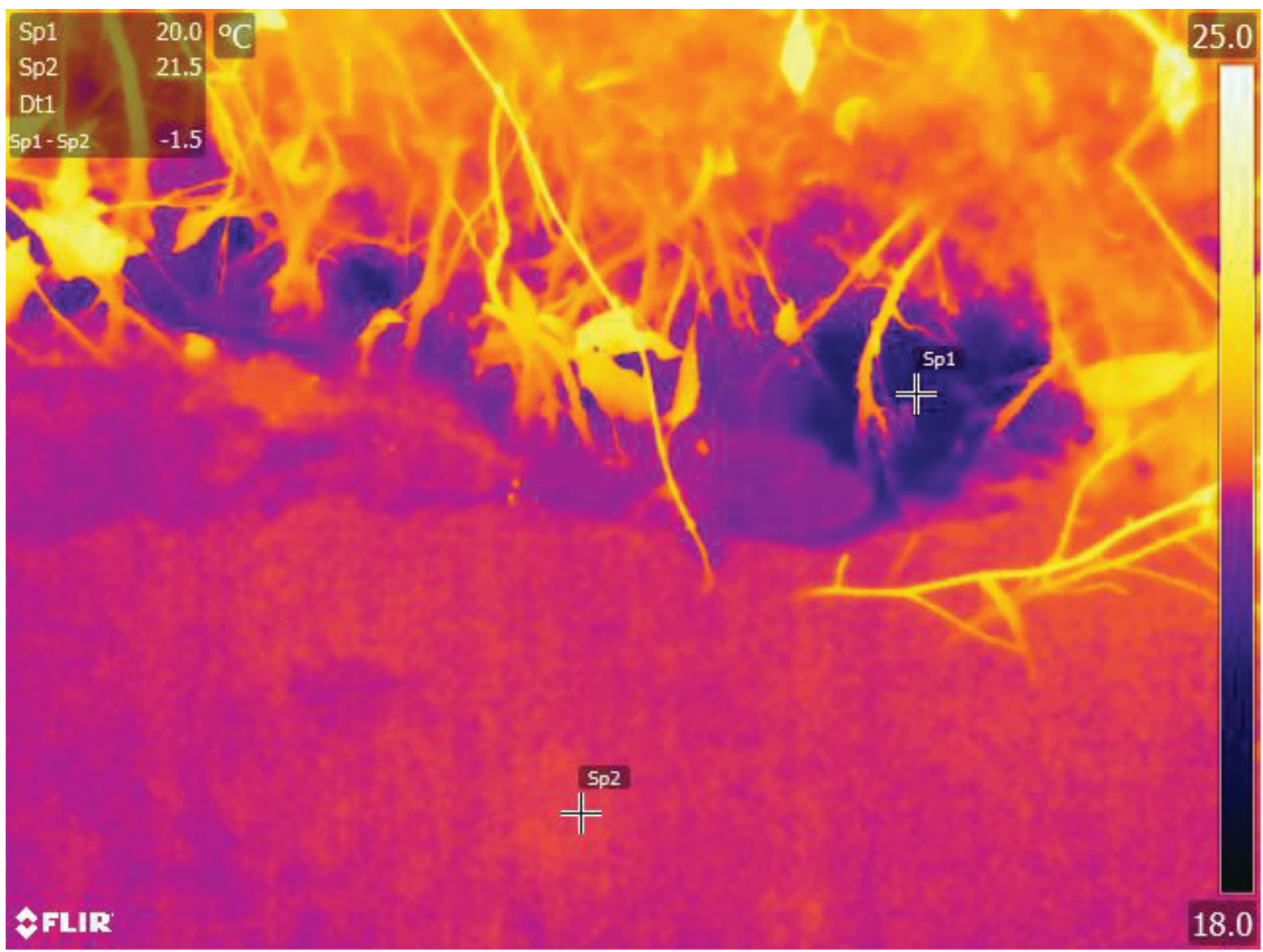

Figure 3-5. Infrared images captured by FLIR camera at site FS-05 to measure stream surface and bank seepage temperature differences in August/September 2014 near the Hemphill Road TCE National Priorities List Superfund site, Gastonia, Gaston County, North Carolina FS-01 to measure stream surface and bank seepage temperature differences in August/ September 2014 near the Hemphill Road TCE National Priorities List Superfund site, Gastonia, Gaston County, North Carolina. 


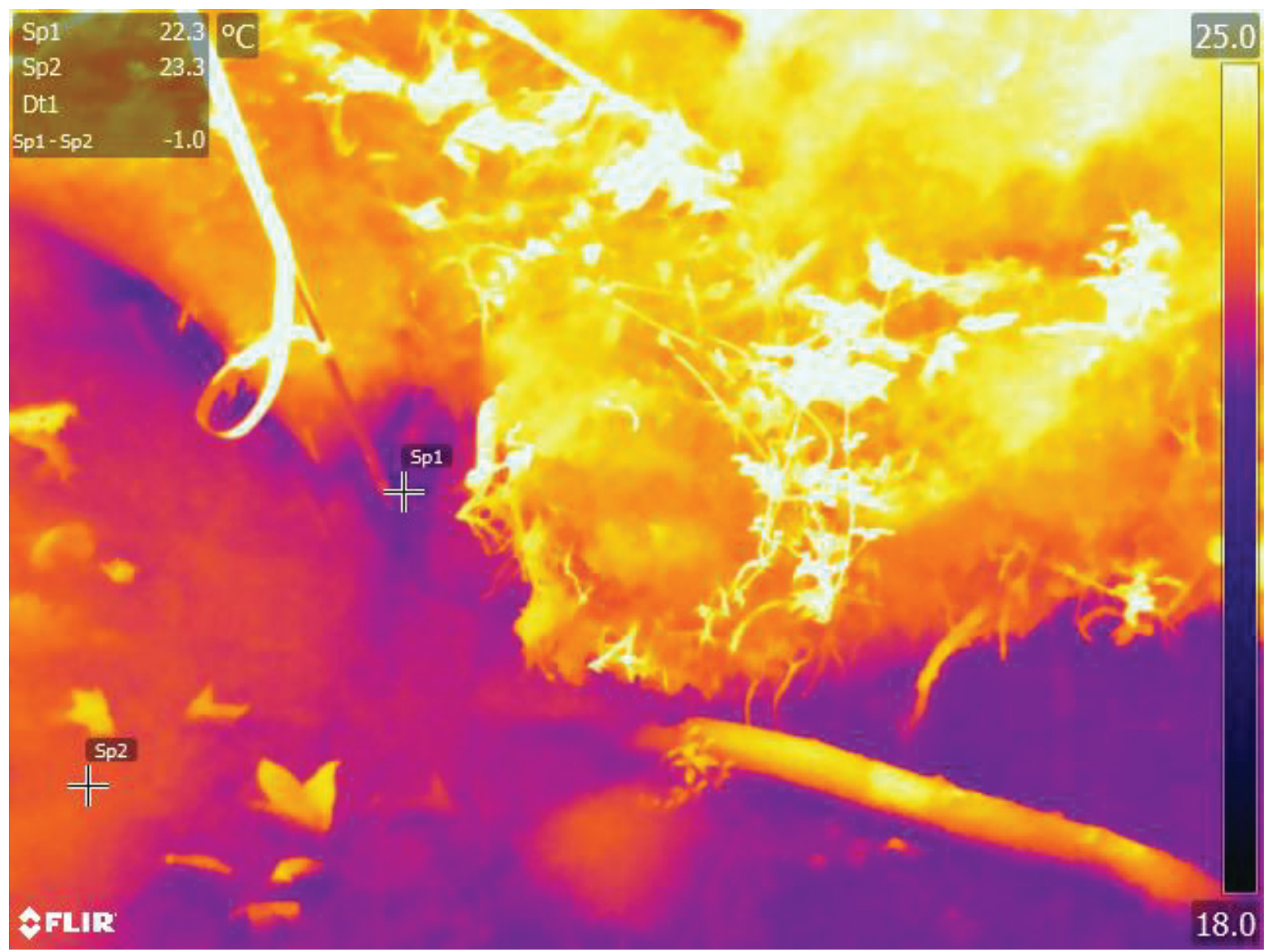

Figure 3-6. Infrared images captured by FLIR camera at site FS-06 to measure stream surface and bank seepage temperature differences in August/September 2014 near the Hemphill Road TCE National Priorities List Superfund site, Gastonia, Gaston County, North Carolina FS-01 to measure stream surface and bank seepage temperature differences in August/ September 2014 near the Hemphill Road TCE National Priorities List Superfund site, Gastonia, Gaston County, North Carolina. 


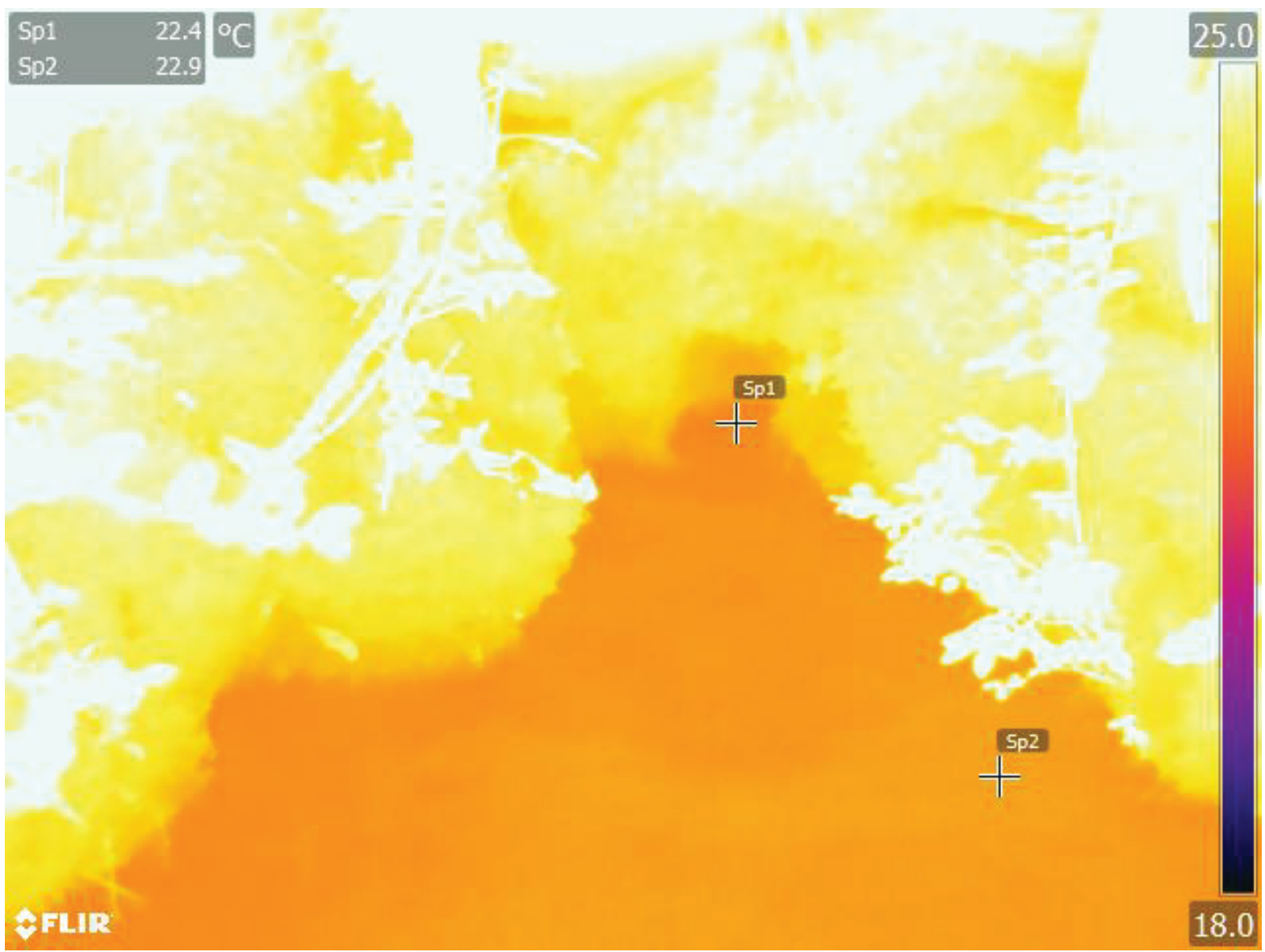

Figure 3-7. Infrared images captured by FLIR camera at site FS-07 to measure stream surface and bank seepage temperature differences in August/September 2014 near the Hemphill Road TCE National Priorities List Superfund site, Gastonia, Gaston County, North Carolina FS-01 to measure stream surface and bank seepage temperature differences in August/ September 2014 near the Hemphill Road TCE National Priorities List Superfund site, Gastonia, Gaston County, North Carolina. 


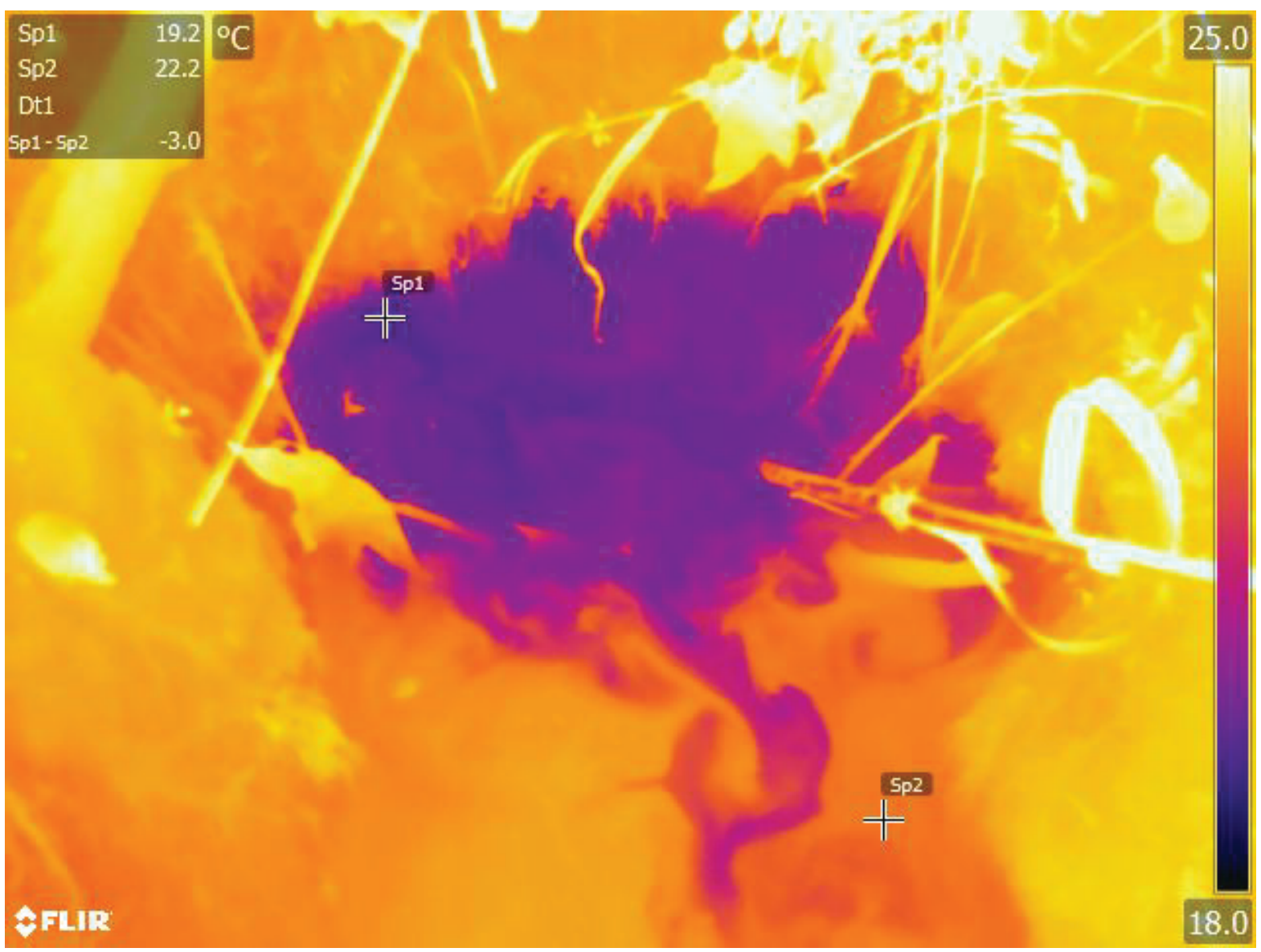

Figure 3-8. Infrared images captured by FLIR camera at site FS-08 to measure stream surface and bank seepage temperature differences in August/September 2014 near the Hemphill Road TCE National Priorities List Superfund site, Gastonia, Gaston County, North Carolina FS-01 to measure stream surface and bank seepage temperature differences in August/ September 2014 near the Hemphill Road TCE National Priorities List Superfund site, Gastonia, Gaston County, North Carolina. 


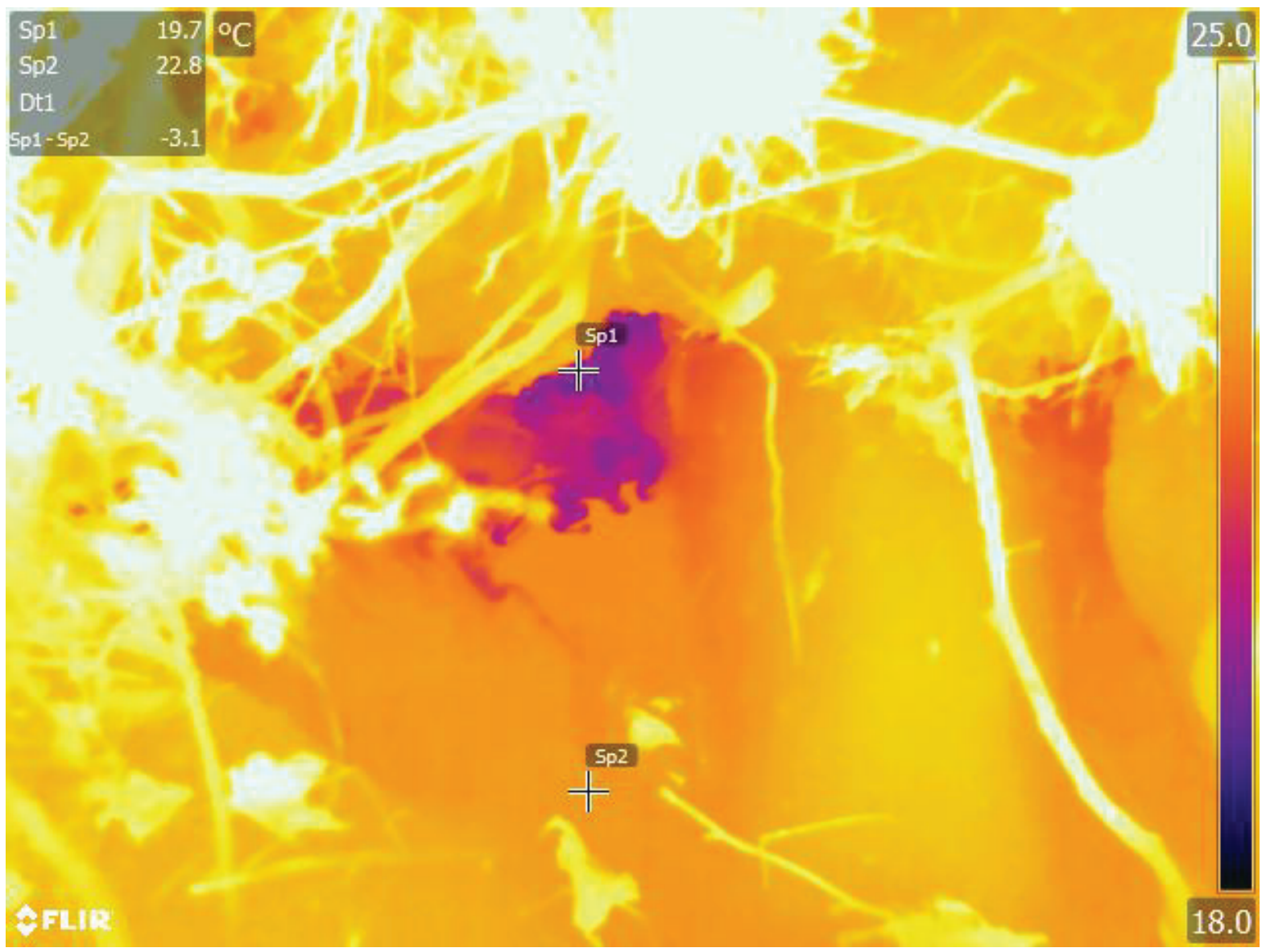

Figure 3-9. Infrared images captured by FLIR camera at site FS-09 to measure stream surface and bank seepage temperature differences in August/September 2014 near the Hemphill Road TCE National Priorities List Superfund site, Gastonia, Gaston County, North Carolina FS-01 to measure stream surface and bank seepage temperature differences in August/ September 2014 near the Hemphill Road TCE National Priorities List Superfund site, Gastonia, Gaston County, North Carolina. 


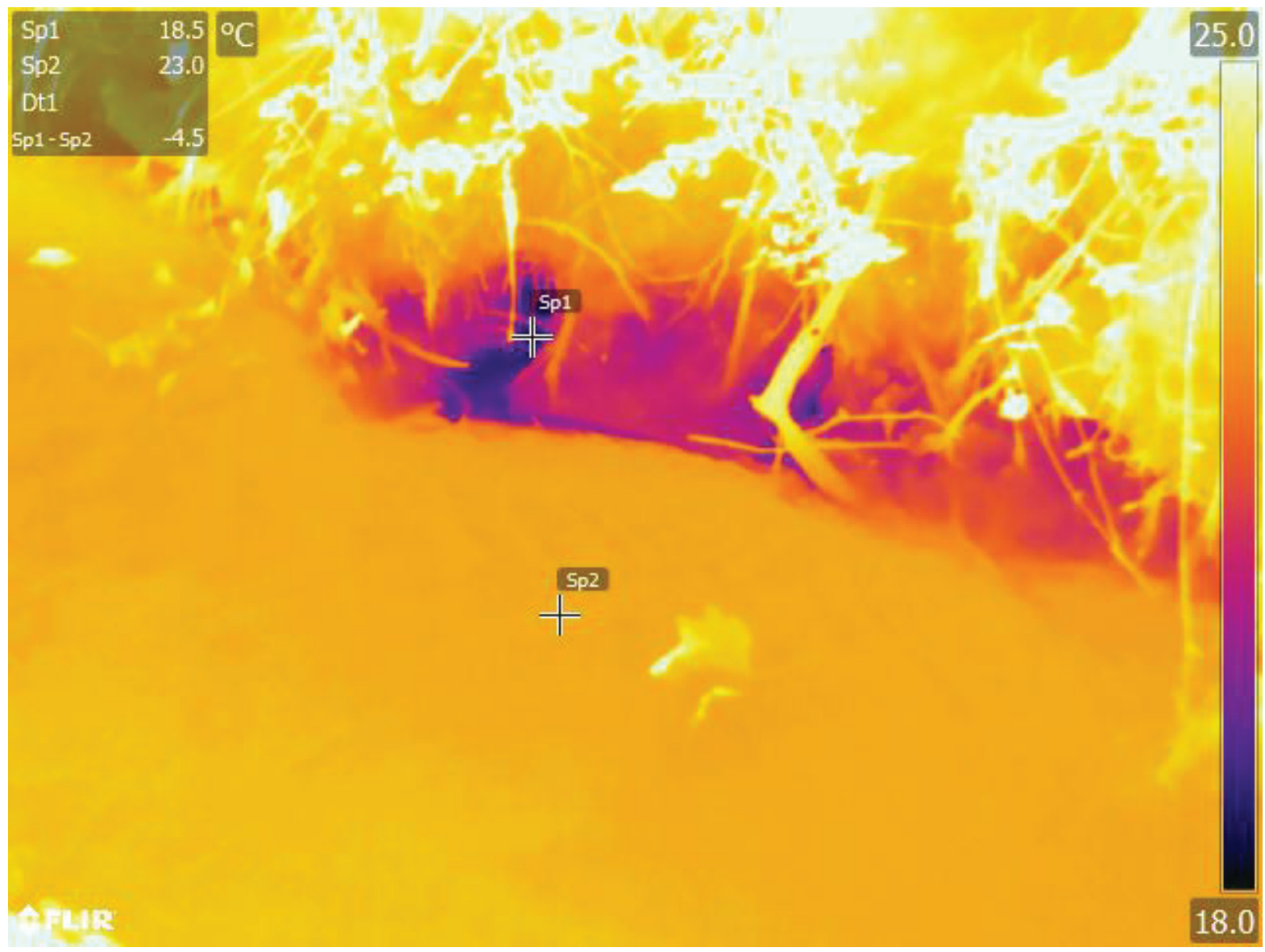

Figure 3-10. Infrared images captured by FLIR camera at site FS-10 to measure stream surface and bank seepage temperature differences in August/September 2014 near the Hemphill Road TCE National Priorities List Superfund site, Gastonia, Gaston County, North Carolina FS-01 to measure stream surface and bank seepage temperature differences in August/ September 2014 near the Hemphill Road TCE National Priorities List Superfund site, Gastonia, Gaston County, North Carolina. 


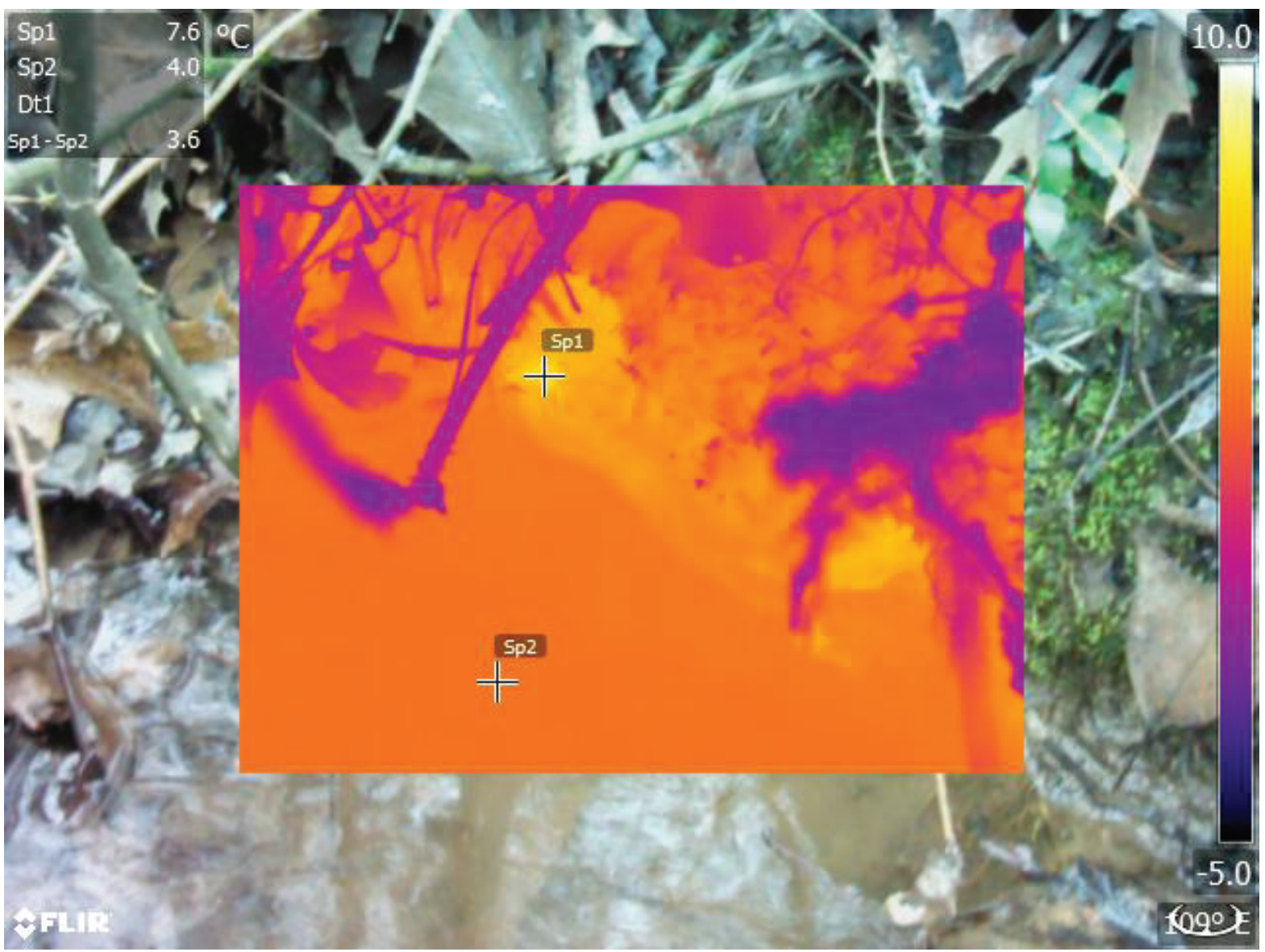

Figure 3-11. Infrared images captured by FLIR camera at site FS-03 to measure stream surface and bank seepage temperature differences in August/September 2014 near the Hemphill Road TCE National Priorities List Superfund site, Gastonia, Gaston County, North Carolina FS-01 to measure stream surface and bank seepage temperature differences in February 2015 near the Hemphill Road TCE National Priorities List Superfund site, Gastonia, Gaston County, North Carolina. 


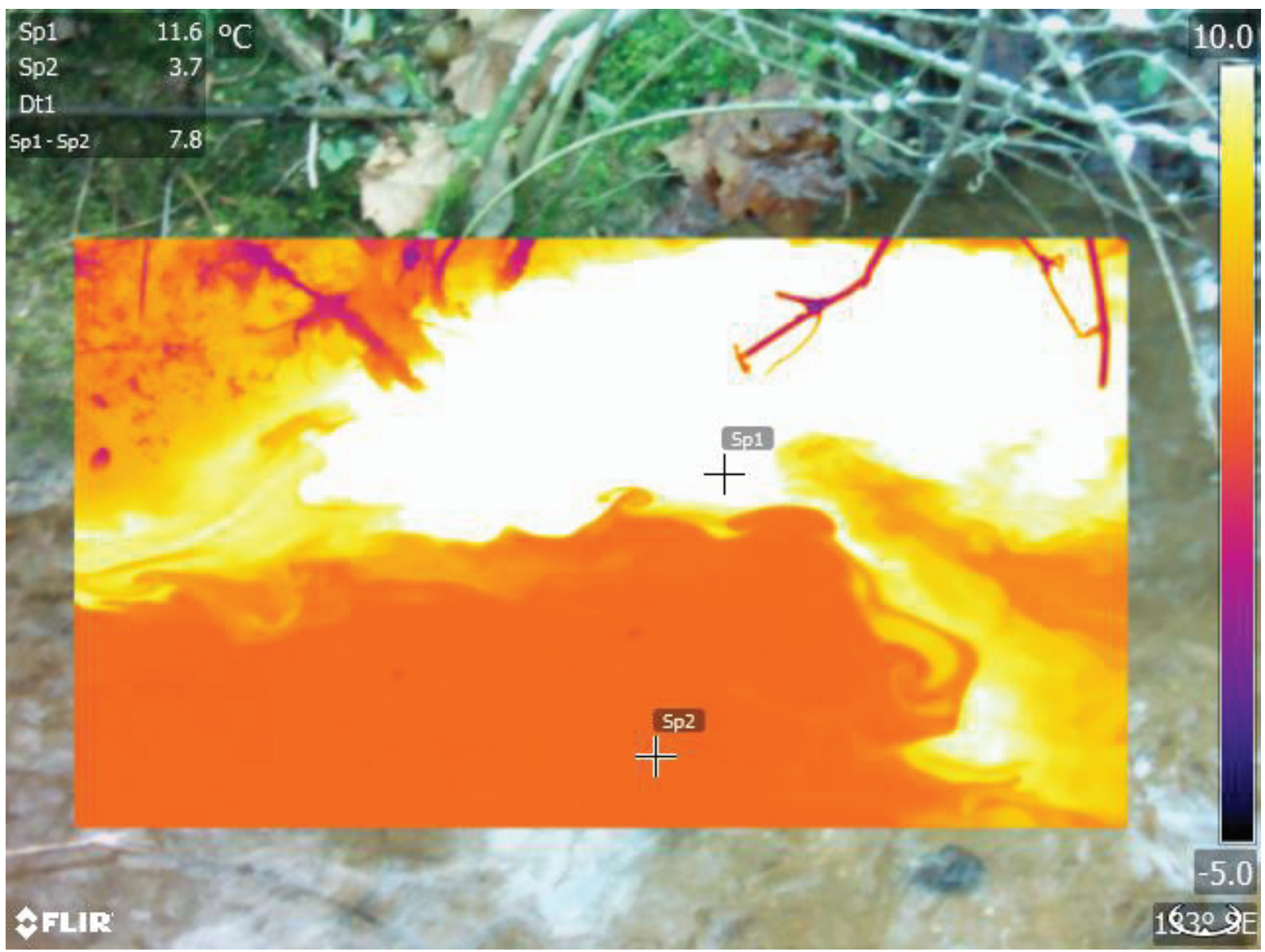

Figure 3-12. Infrared images captured by FLIR camera at site FS-04 to measure stream surface and bank seepage temperature differences in August/September 2014 near the Hemphill Road TCE National Priorities List Superfund site, Gastonia, Gaston County, North Carolina FS-01 to measure stream surface and bank seepage temperature differences in February 2015 near the Hemphill Road TCE National Priorities List Superfund site, Gastonia, Gaston County, North Carolina. 


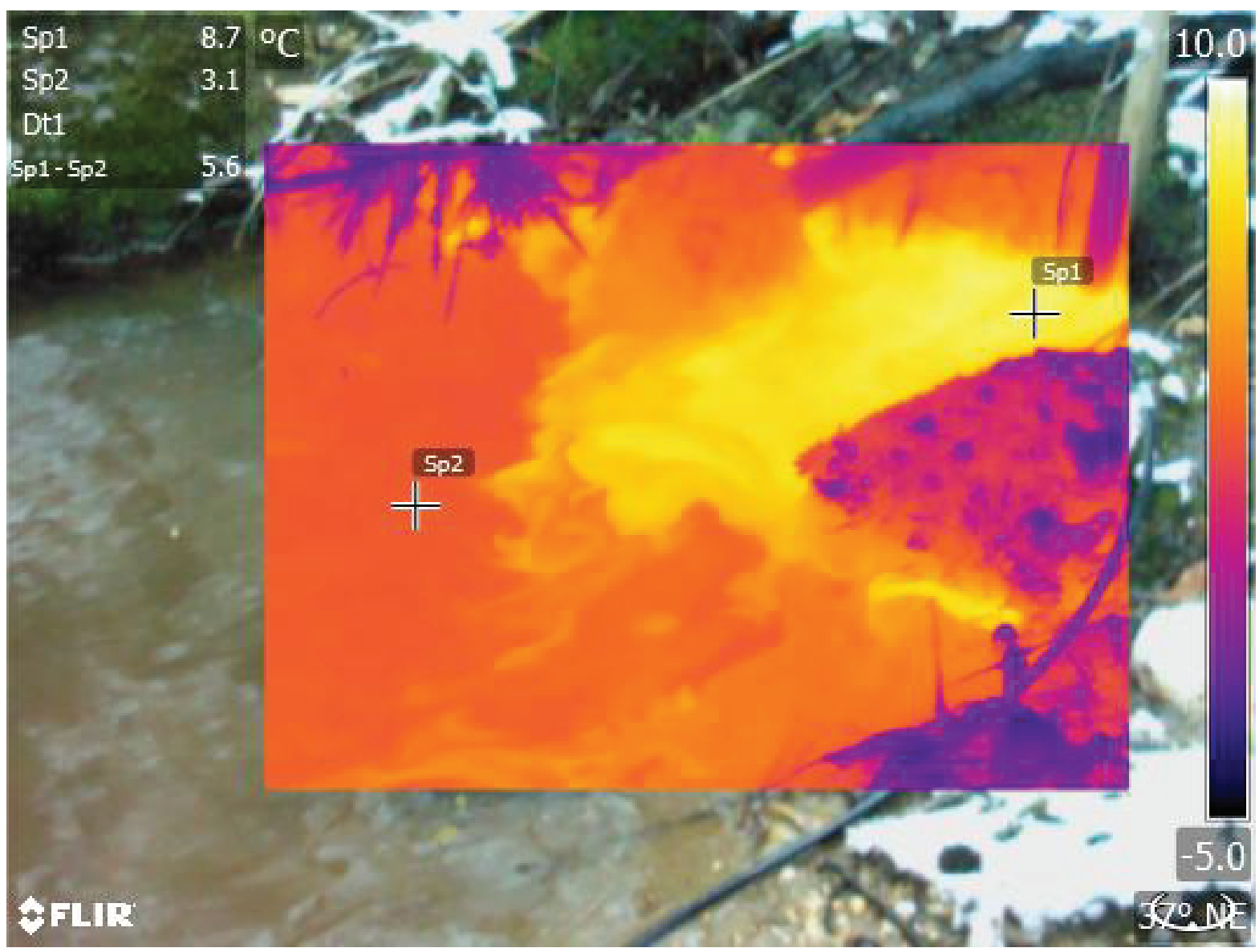

Figure 3-13. Infrared images captured by FLIR camera at site FS-08 to measure stream surface and bank seepage temperature differences in August/September 2014 near the Hemphill Road TCE National Priorities List Superfund site, Gastonia, Gaston County, North Carolina FS-01 to measure stream surface and bank seepage temperature differences in February 2015 near the Hemphill Road TCE National Priorities List Superfund site, Gastonia, Gaston County, North Carolina. 


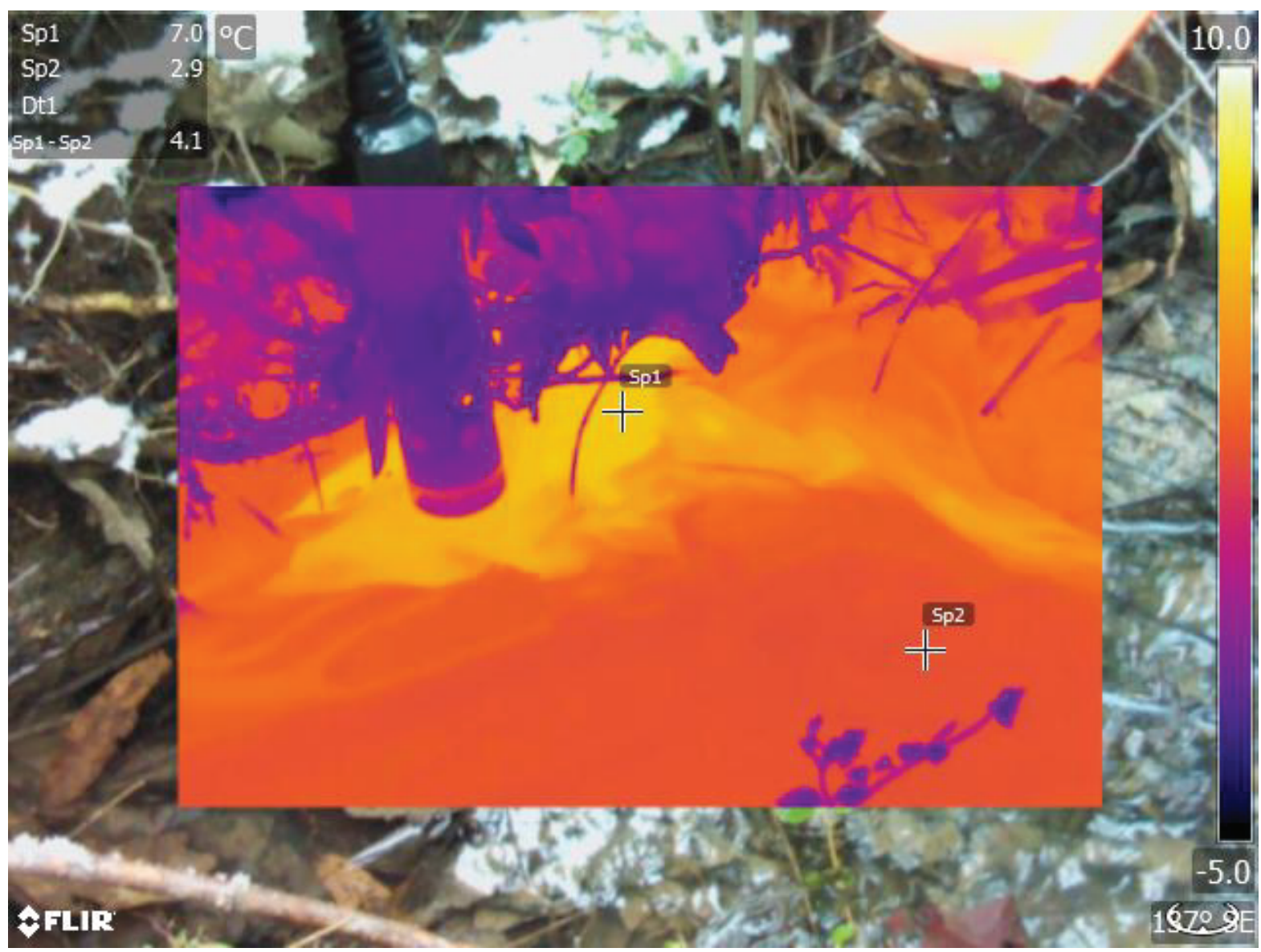

Figure 3-14. Infrared images captured by FLIR camera at site FS-09 to measure stream surface and bank seepage temperature differences in August/September 2014 near the Hemphill Road TCE National Priorities List Superfund site, Gastonia, Gaston County, North Carolina FS-01 to measure stream surface and bank seepage temperature differences in February 2015 near the Hemphill Road TCE National Priorities List Superfund site, Gastonia, Gaston County, North Carolina. 


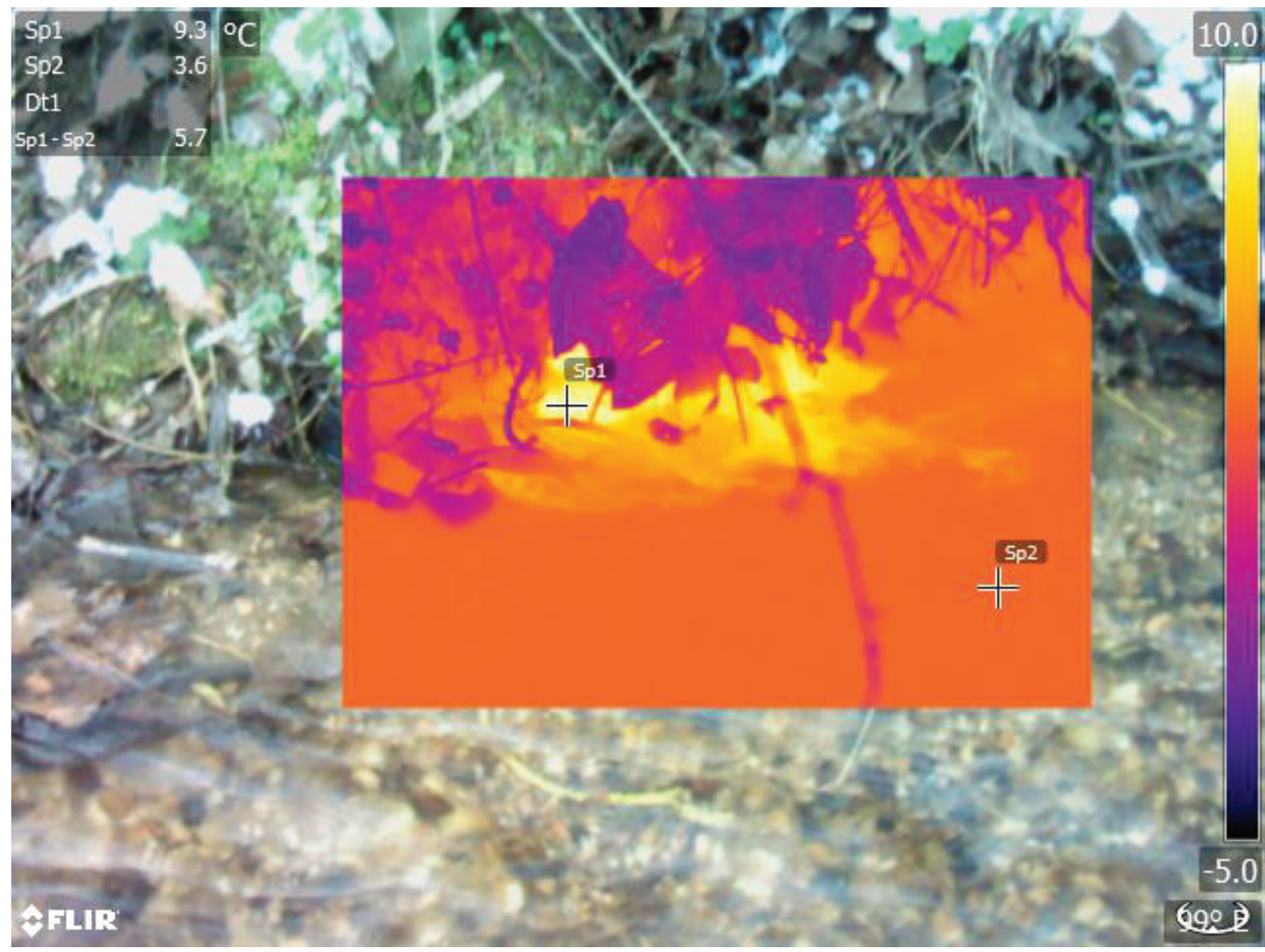

Figure 3-15. Infrared images captured by FLIR camera at site FS-10 to measure stream surface and bank seepage temperature differences in August/September 2014 near the Hemphill Road TCE National Priorities List Superfund site, Gastonia, Gaston County, North Carolina FS-01 to measure stream surface and bank seepage temperature differences in February 2015 near the Hemphill Road TCE National Priorities List Superfund site, Gastonia, Gaston County, North Carolina. 
Manuscript approved on February 10, 2017

Prepared by the USGS Science Publishing Network

For additional information regarding this publication, please contact:

Director, South Atlantic Water Science Center

U.S. Geological Survey

720 Gracern Road

Stephenson Center, Suite 129

Columbia, SC 29210

(803) 750-6100

Or visit the South Atlantic Water Science Center website at

https://www2.usgs.gov/water/southatlantic/ 


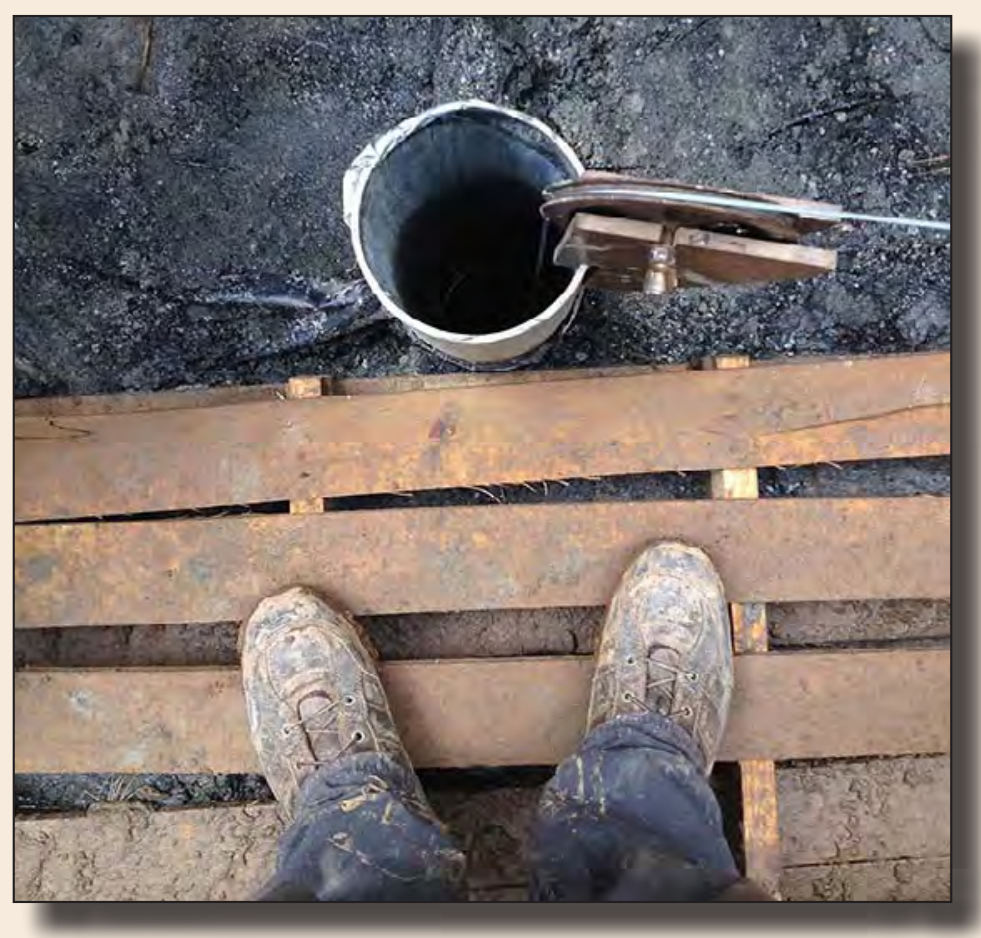

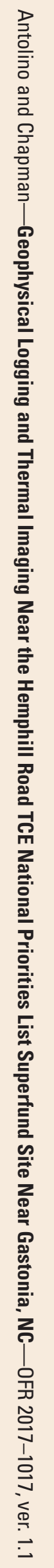

